\title{
The Role of PPAR $\gamma$ Ligands in Breast Cancer: From Basic Research to Clinical Studies
}

\author{
Giuseppina Augimeri ${ }^{1}$, Cinzia Giordano ${ }^{1,2}$, Luca Gelsomino ${ }^{1}$, Pierluigi Plastina ${ }^{1}(\mathbb{D}$, \\ Ines Barone ${ }^{1,2} \mathbb{D}$, Stefania Catalano ${ }^{1,2}$, Sebastiano Andò ${ }^{1}$ and Daniela Bonofiglio ${ }^{1,2, * \mathbb{D}}$ \\ 1 Department of Pharmacy, Health and Nutritional Sciences, University of Calabria, \\ 87036 Arcavacata di Rende (CS), Italy; giusy.augimeri@gmail.com (G.A.); cinzia.giordano@unical.it (C.G.); \\ luca.gelsomino@unical.it (L.G.); pierluigi.plastina@unical.it (P.P.); ines.barone@unical.it (I.B.); \\ stefcatalano@libero.it (S.C.); sebastiano.ando@unical.it (S.A.) \\ 2 Centro Sanitario, University of Calabria, 87036 Arcavacata di Rende (CS), Italy \\ * Correspondence: daniela.bonofiglio@unical.it; Tel.: +39-0984-496208
}

Received: 7 August 2020; Accepted: 12 September 2020; Published: 14 September 2020

Simple Summary: Breast cancer represents the most frequently diagnosed carcinoma and the leading cause of cancer death in women. Despite advances achieved in systemic therapy, about one-third of all patients relapse and develop a metastatic disease, which ultimately leads to breast cancer deaths. In this scenario, the identification of new prognostic factors and pharmacological tools is needed to improve breast cancer management. Peroxisome proliferator-activated receptor gamma (PPAR $\gamma$ ), belonging to the nuclear receptor superfamily, is a ligand-dependent transcription factor expressed in many tumors including breast cancer, and its function upon binding of ligands has been linked to the tumor development, progression and metastasis. Over the last decade, much research has focused on the implication of natural and synthetic PPAR $\gamma$ agonists in the negative regulation of breast cancer growth and progression. The aim of the present review is to summarize the role of PPAR $\gamma$ activation in breast cancer from the basic research to clinical studies. The therapeutic effects of natural and synthetic PPAR $\gamma$ ligands, as antineoplastic agents, represent a fascinating and clinically a potential translatable area of research with regards to the battle against cancer.

\begin{abstract}
Peroxisome proliferator-activated receptor gamma (PPAR $\gamma$ ), belonging to the nuclear receptor superfamily, is a ligand-dependent transcription factor involved in a variety of pathophysiological conditions such as inflammation, metabolic disorders, cardiovascular disease, and cancers. In this latter context, PPAR $\gamma$ is expressed in many tumors including breast cancer, and its function upon binding of ligands has been linked to the tumor development, progression, and metastasis. Over the last decade, much research has focused on the potential of natural agonists for PPAR $\gamma$ including fatty acids and prostanoids that act as weak ligands compared to the strong and synthetic PPAR $\gamma$ agonists such as thiazolidinedione drugs. Both natural and synthetic compounds have been implicated in the negative regulation of breast cancer growth and progression. The aim of the present review is to summarize the role of PPAR $\gamma$ activation in breast cancer focusing on the underlying cellular and molecular mechanisms involved in the regulation of cell proliferation, cell cycle, and cell death, in the modulation of motility and invasion as well as in the cross-talk with other different signaling pathways. Besides, we also provide an overview of the in vivo breast cancer models and clinical studies. The therapeutic effects of natural and synthetic PPAR $\gamma$ ligands, as antineoplastic agents, represent a fascinating and clinically a potential translatable area of research with regards to the battle against cancer.
\end{abstract}

Keywords: peroxisome proliferator-activated receptor gamma; synthetic PPAR $\gamma$ agonists; thiazolidinediones; selective PPAR $\gamma$ modulators; nonsteroidal anti-inflammatory drugs; natural PPAR $\gamma$ agonists; 15-deoxy-D12,14-prostaglandin J2; omega-3 polyunsaturated fatty acids; PUFA 


\section{Introduction}

Breast cancer represents the most frequently diagnosed carcinoma and the leading cause of cancer death in women [1]. In 2018, 2.1 million new cases and 626,679 deaths were recorded, making the management of breast cancer a public health priority [2]. Based on the gene expression of the standard molecular markers, estrogen receptor $\alpha(E R \alpha)$, progesterone receptor (PR), and human epidermal growth factor receptor 2 (HER2), breast cancer is categorized in four main subtypes: Luminal A (ER $\alpha$ and/or PR positive and HER2 negative); Luminal B (ER $\alpha$ and/or PR positive and HER2 positive or negative); HER2-positive (ER $\alpha / \mathrm{PR}$ negative and HER2 positive); Triple-negative, TNBC (ER $\alpha / \mathrm{PR} / \mathrm{HER} 2$ negative), each characterized by different prognosis and response to drug treatment [3,4]. Currently, locoregional (surgery and radiotherapy) and systemic (chemotherapy, endocrine, and biological therapy) approaches represent the main therapeutic options for the treatment of breast cancer [5]. Despite advances achieved in systemic therapy, approximately 30\% of patients relapse and develop a metastatic disease, which ultimately leads to breast cancer deaths [6,7]. Particularly, patients with TNBC, which accounts for $10-20 \%$ of all cases of breast carcinoma, have a relatively poor outcome and require additional treatment approaches since this tumor subtype is characterized by the lack of biomarker expression [8]. In this scenario, the identification of new prognostic factors and pharmacological tools is needed to improve breast cancer management. Apart from ER $\alpha$ and PR, numerous nuclear receptors, including the androgen receptor (AR), the vitamin D3 receptor (VDR), the retinoid X receptors (RXR), and the farnesoid $\mathrm{X}$ receptor (FXR) have been investigated as potential novel targets for the treatment of breast cancer because of their role as key regulators of gene expression [9-12]. In the last decades, the peroxisome proliferator-activated receptor $\gamma(\operatorname{PPAR} \gamma)$, a ligand-activated transcription factor, which has been mainly characterized as a pivotal regulator of adipocyte differentiation, has also received considerable attention for its role in breast cancer tumorigenesis [13,14]. Clinical studies revealed that PPAR $\gamma$ expression represents a positive prognostic factor in luminal and ductal breast cancer patients [15], since higher levels of PPAR $\gamma$ inversely correlate with grade, tumor size, and TNM staging system of malignant tumor $[16,17]$. Interestingly, activation of PPAR $\gamma$ by its natural and synthetic agonists has been found to modulate the expression of several genes associated with tumorigenesis, further highlighting that this nuclear receptor could represent a new promising target for the treatment of breast cancer. Synthetic PPAR $\gamma$ agonists, including the antidiabetic drugs thiazolidinediones (TZDs), demonstrated to induce growth inhibition, apoptosis, and differentiation of breast cancer cells in in vitro and in vivo models [18]. Although clinical trials in breast cancer patients fail to show the expected therapeutic values of TDZs [19], encouraging results have been obtained using natural PPAR $\gamma$ ligands in breast cancer. These compounds, including omega-3 ( $\omega-3)$ fatty acids and their derivatives, have proven to be promising therapeutic agents in the prevention and treatment of breast cancer [20-22]. We herein summarize the current knowledge of the role of PPAR $\gamma$ and its natural and synthetic ligands in breast cancer providing an overview from in vitro experiments to in vivo and clinical studies. This review could allow a better comprehension of the PPAR $\gamma$ agonists as potential pharmacological or nutritional compounds against breast cancer.

\section{Search Strategy and Data Extraction}

A search for original articles published between 1997 and 2020 was performed in PubMed. The literature search was performed using the following keywords: "PPAR $\gamma$ " AND "cancer" obtaining 3774 papers. A total of 647 published papers were restricted when we used as keywords "PPAR $\gamma$ " AND "breast cancer." In order to focus our attention on PPAR $\gamma$ ligands, "natural PPAR $\gamma$ ligands" AND "breast cancer" (37 papers) or "synthetic PPAR $\gamma$ ligands" AND “breast cancer" (46 papers) or " $\omega 3$ 3" AND "PPAR $\gamma$ " AND "breast cancer" (22 papers) keywords were used. All articles selected were full-text articles written in English. After removing the duplicates, the articles were screened based on their relevance to the topic and all irrelevant papers were excluded. We also identified further relevant articles from the reference lists of selected papers. The data reviewed have been organized in separate sections including: (1) structure, distribution, and mechanism of action of PPAR $\gamma$; (2) synthetic and 
natural PPAR $\gamma$ ligands; and (3) role of the PPAR $\gamma$ ligands in breast cancer. Finally, PPAR $\gamma$ ligands have been highlighted as potential breast cancer therapeutic agents both from a nutritional and a pharmacological perspective.

\section{Peroxisome Proliferator-Activated Receptor $\gamma$ : Structure, Distribution, and Mechanism of Action}

\subsection{Genomic Organization and Tissue Distribution of PPAR $\gamma$}

PPAR $\gamma$ is a ligand-activated transcription factor belonging to the PPARs family, which also comprises PPAR $\alpha$ and PPAR $\beta / \delta$ [23]. The human PPAR $\gamma$ gene, NR1C3, is located on the chromosome 3p25.2 and contains about 9 exons, which give rise to three different PPAR $\gamma$ transcripts $(\gamma 1, \gamma 2$, and $\gamma 3$ ) by alternative promoter usage and splicing [24,25]. PPAR $\gamma 1$ and PPAR $\gamma 3$ mRNAs encode the same protein, whereas PPAR $\gamma 2$ protein contains 30 additional amino-acids in the N-terminal region. PPAR $\gamma 1$ mRNA has ubiquitous expression, although the highest levels were found in the adipose tissue; PPAR $\gamma 2$ mRNA is mainly expressed in the adipocytes; PPAR $\gamma 3$ mRNA has been highly found in macrophages and adipose tissue [26]. However, regardless of PPAR $\gamma$ subtypes, several types of cells express different levels of PPAR $\gamma$. High levels of PPAR $\gamma$ protein expression were found in the adipose tissue, large intestine, and hematopoietic cells, whereas lower amounts of PPAR $\gamma$ were revealed in the kidney, liver, and small intestine [24]. Interestingly, PPAR $\gamma$ is also expressed in different types of tumors, including colon, prostate, and breast cancer [27]. PPAR $\gamma$ has been found not only in the epithelial cancer cells but also in several components of the tumor microenvironment [28-30], such as tumor-associated macrophages (TAMs) and cancer-associated fibroblasts (CAFs), suggesting that PPAR $\gamma$ may be a good target for integrative therapies affecting simultaneously tumors and their microenvironment.

\subsection{PPAR $\gamma$ Domain Structure}

The structural organization of PPAR $\gamma$ consists of five different domains named "A-E" from $\mathrm{N}$ - to C-terminus (Figure 1a). The $\mathrm{N}$-terminus domain (A/B domain) is the most variable domain among the nuclear receptor family, and it contains the ligand-independent activation factor 1 (AF-1) region, that once phosphorylated modulates PPAR $\gamma$ activity [31]. The central DNA-binding domain (C domain) is the most conservative region, and it is involved in the binding of PPAR $\gamma$ to the DNA, after its heterodimerization with retinoid $X$ receptor (RXR). The $C$ domain consists of two zinc fingers composed of nine cysteines that recognize and bind the PPAR response elements (PPRE) in the promoter region of PPAR-response genes, regulating their transcription [31,32]. The consensus sequence of PPRE is composed of two direct repeat (DR)-1 elements consisting of two AGGTCA sequences separated by a single nucleotide spacer [31,33]. The $\mathrm{D}$ domain is a flexible hinge region connecting the $\mathrm{C}$ domain to the ligand-binding domain (E domain), which, in turn, is involved in the ligand recognition and binding [32]. Information from crystal structure has revealed that the ligand binding "pocket" of PPAR $\gamma$ is larger than other nuclear receptor, enabling the interaction of several compounds [23] (Figure 1b, https://www.rcsb.org/3d-view/2F4B/1). In the C-terminus, the F domain contains the ligand-dependent activation domain (AF-2), an amphipathic helix involved in the docking of coactivator proteins in response to ligand stimulation $[31,34]$. 


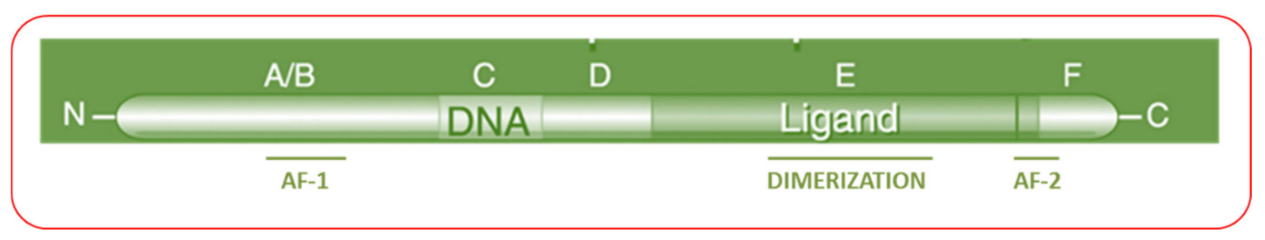

(a)

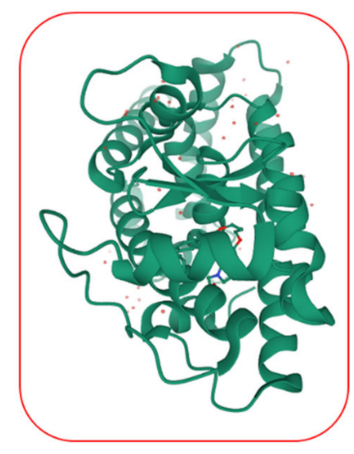

(b)

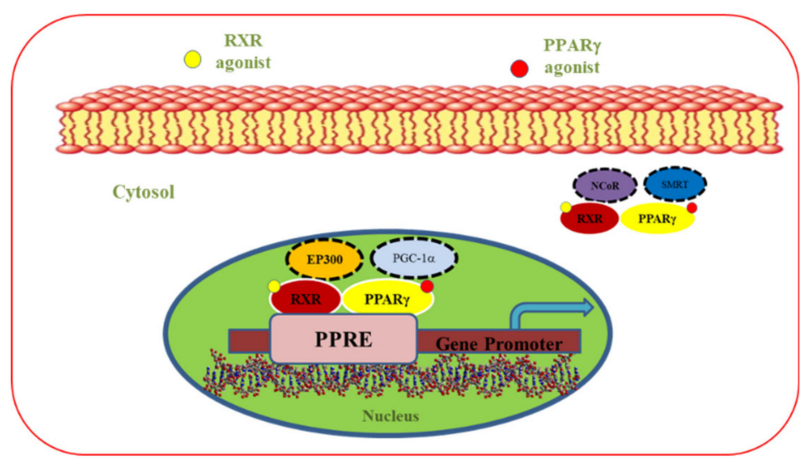

(c)

Figure 1. Modular domain (a) and crystal (b) structures of the peroxisome proliferator-activated receptor gamma (PPAR $\gamma)$. Ligand-binding activity of the PPAR $\gamma$ and retinoid $X$ receptors (RXR) heterodimer, which is bound in the cytosol to the nuclear receptor corepressor complexes (N-CoR) or silencing mediator of retinoic acid and thyroid hormone receptor (SMRT), while in the nucleus is activated by PPAR $\gamma$ coactivator $1-\alpha$ (PGC-1 $\alpha$ ) or binding protein $\mathrm{p} 300$ (EP300) for binding to the PPRE in the promoter of target genes (c).

\subsection{The Mechanism of Action of PPAR $\gamma$}

Like other members of the nuclear receptor family, PPAR $\gamma$ activity depends on its intracellular localization. In absence of ligands, PPAR $\gamma$ is localized in the cytoplasm bound to transcriptional corepressor complexes containing the nuclear receptor corepressor complexes $(\mathrm{N}-\mathrm{CoR})$ or silencing mediator of retinoic acid and thyroid hormone receptor (SMRT), which prevents PPAR $\gamma$ activation. Upon stimulation by own ligands, PPAR $\gamma$ undergoes a conformational change in AF2 domain which, through the replacement of the corepressor with the coactivator complex, consisting of proteins such as PPAR $\gamma$ coactivator 1- $\alpha$ (PGC-1 $\alpha$ ) or binding protein p300 (EP300), vitamin D receptor-interacting protein (DRIP), or thyroid hormone receptor-associated protein (TRAP), induces PPAR $\gamma$ activation [35,36]. Thus, PPAR $\gamma$ forms a heterodimer with RXR and acquires the ability to translocate into the nucleus and binds to the PPRE in the PPAR $\gamma$ target genes. Then, the coactivator multiprotein complex, containing histone acetylase enzymes, remodels the chromatin structure and allows the binding of RNA polymerase to the promoter of PPAR $\gamma$ target genes, initiating their transcription (Figure 1c) [37]. Till date, more than 100 genes have been identified as PPAR $\gamma$-regulated factors, including those involved in lipid metabolism, glucose homeostasis, adipocyte differentiation, and tumorigenesis [38]. However, only a restricted number of functional PPREs have been discovered, limiting the possibility to completely categorized the PPAR $\gamma$ direct target genes. Indeed, the majority of the endogenous PPREs deviates from the consensus sequence and contains degenerate PPRE-like sequences, such as $C-X-C$ chemokine receptor type 4 (CXCR4, AGGATAcAGATGA) [39], scavenger receptor class B member 1 (SR-BI, AGGAGAAAGG GGA) [40], and sodium-hydrogen antiporter 1 (NHE-1, GGTCAnnAGTTCG) [41] that are difficult to be identified since the extent of tolerable sequence variability in the PPRE is not completely understood [42]. Interestingly, it has been demonstrated that PPAR $\gamma$ ligands can cooperate with RXR ligands to modulate the transcription of PPAR $\gamma$ target genes [43]. In this view, PPAR $\gamma$ and RXR agonists may be used in low doses to achieve maximum pharmacological outcomes 
with low potential side effects $[44,45]$. PPAR $\gamma$ can regulate gene expression also through nongenomic mechanisms [31]. It has been demonstrated that PPAR $\gamma$ physically interacts with different transcription factors such as nuclear factor kappa-light-chain-enhancer of activated B (NFkB) and activator protein 1 (AP-1), blocking the expression of pro-inflammatory genes through transrepression mechanisms in a DNA-independent manner [46]. The anti-inflammatory effects of PPAR $\gamma$ have been extensively studied, but the mechanisms whereby PPAR $\gamma$ reduces the expression of pro-inflammatory genes are not completely understood [47]. Although the functions of PPAR $\gamma$ are mainly regulated through ligand binding, post-transcriptional modification, including phosphorylation, SUMOylation, ubiquitination, and nitration occur in specific sites of the AF-1 domain, regulating PPAR $\gamma$ activity [48]. The PPAR $\gamma$ domain and crystal structures along with the mechanism of action of this nuclear receptor are depicted in Figure 1.

\section{PPAR $\gamma$ Agonists}

\subsection{Natural PPAR $\gamma$ Ligands}

Over the last years, natural PPAR $\gamma$ ligands have received much attention because they activate PPAR $\gamma$ inducing numerous beneficial effects with fewer side effects compared to synthetic agonists. Natural PPAR $\gamma$ ligands include unsaturated fatty acids and their derivatives. In particular, PPAR $\gamma$ is preferentially activated by polyunsaturated fatty acids (PUFAs), such as $\omega-3$ and $\omega-6$ PUFAs derived from dietary sources $[23,49]$. $\omega-3$ PUFAs, including eicosapentaenoic acid (EPA) and docosahexaenoic acid (DHA), and their derivatives, represent the most interesting class of natural PPAR $\gamma$ agonists since their dietary intake is associated with health benefits [50]. Indeed, several studies have reported that the consumption of $\omega$-3-PUFA-rich foods, such as fish and walnuts, is associated with a decreased incidence of cardiovascular diseases and a reduced risk to develop different types of malignancy, including colorectal, prostate, and breast cancer [20,51,52]. In addition, it has been reported that consumption of $\omega-3$ PUFAs correlates with increased insulin sensitivity [53] as well as improvement of the immune profile and cognition [54-56]. Among different molecular mechanisms by which $\omega-3$ PUFAs exert their effects, it has been demonstrated that several $\omega-3$ PUFA biological activities depend on the activation of PPAR $\gamma$. Recently, it has been shown that DHA-rich fish oil supplementation reduces the triglyceride level in patients with type 2 diabetes in a PPAR $\gamma$-dependent manner [57]. Interestingly, $\omega-3$ PUFAs can be metabolized in intermediates, such as 17-hydroxy- and 7-hydroxy-DHA, which activate PPAR $\gamma$ more than parental compounds [58]. Moreover, $\omega-3$ PUFAs conjugated with ethanolamine, dopamine, serotonin, or other amines have been extensively studied for their ability to activate PPAR $\gamma$ and are found to exert stronger effects than the unconjugated related compounds, but their molecular mechanism is not fully understood [59]. Recently, it has been demonstrated that the conjugates of DHA with ethanolamine (DHEA) or serotonin (DHA-5-HT) decrease the cytokine secretion by TAMs of breast cancer in a PPAR $\gamma$-dependent manner, reprogramming TAMs in a less aggressive phenotype [30]. Apart from $\omega-3$ PUFAs, $\omega-6$ PUFAs and their derivatives are also natural PPAR $\gamma$ ligands. Moreover, 9-Hydroxyoctadecadienoic acid (9-HODE) and 13-Hydroxyoctadecadienoic acid (13-HODE) derived from $\omega-6$ linoleic acid and 15-deoxy- $\Delta^{12,14}$-prostaglandin J2 (15d-PGJ2) obtained from $\omega-6$ arachidonic acid are important endogenous PPAR $\gamma$ ligands, showing a broad range of effects, including anti-inflammatory and antineoplastic actions. Other molecules, such as nitrated fatty acids derived from nonenzymatic reactions of unsaturated fatty acids and endogenous nitric oxide, have been described as endogenous PPAR $\gamma$ ligands. These compounds, through PPAR $\gamma$ activation, induce anti-inflammatory effects, adipocyte differentiation and glucose uptake in in vitro models, but their biological role in humans is not clarified [60,61].

Other than PUFAs and their derivatives, numerous classes of bioactive compounds obtained from plant extracts, including flavonoids, neolignans, and sequiterpenes, have been identified as PPAR $\gamma$ ligands [62,63]. Most of them, such as genistein, quercetin, and luteolin displayed partial agonism profile on PPAR $\gamma$. However, a complete categorization of bioactive compounds as PPAR $\gamma$ agonists 
is still missing because of the high number of active extracts that can induce PPAR $\gamma$ activation [62]. In Table 1, we have reported the most characterized natural PPAR $\gamma$ ligands.

Table 1. Class, common as well as IUPAC name, and chemical structure of natural peroxisome proliferator-activated receptor gamma $(\operatorname{PPAR} \gamma)$ ligands.

\begin{tabular}{|c|c|c|c|c|}
\hline Class & Common Name & IUPAC NAME & Chemical Structure & References \\
\hline \multirow{2}{*}{$\omega-3$ PUFAs ${ }^{1}$} & $\begin{array}{l}\text { Eicosapentaenoic acid (EPA) } \\
20: 5(\omega-3)\end{array}$ & $\begin{array}{c}\text { (5Z,8Z,11Z,14Z,17)-Eicosa- } \\
\text { 5,8,11,14,17-pentaenoic acid }\end{array}$ & & {$[64,65]$} \\
\hline & $\begin{array}{l}\text { Docosahexaenoic acid (DHA) } \\
22: 6(\omega-3)\end{array}$ & $\begin{array}{c}(4 Z, 7 Z, 10 Z, 13 Z, 16 Z, 19 Z)- \\
\text { Docosa-4,7,10,13,16,19- hexaenoic } \\
\text { acid }\end{array}$ & & {$[57,66]$} \\
\hline \multirow[t]{5}{*}{$\begin{array}{l}\omega-3 \text { PUFA } \\
\text { conjugates }\end{array}$} & $\begin{array}{l}\text { Eicosapentaenoyl ethanolamine } \\
\text { (EPEA) }\end{array}$ & $\begin{array}{c}\text { (5Z,8Z,11Z,14Z,17)- } N \text { - } \\
\text { (2-Hydroxyethyl)-eicosa- } \\
5,8,11,14,17 \text {-pentaenamide }\end{array}$ & & [21] \\
\hline & $\begin{array}{l}\text { Docosahexaenoyl ethanolamine } \\
\text { (DHEA) }\end{array}$ & $\begin{array}{c}\text { (4Z,7Z,10Z,13Z,16Z,19Z)-N- } \\
\text { (2-Hydroxyethyl)-docosa- } \\
\text { 4,7,10,13,16,19-hexaenamide }\end{array}$ & & [21] \\
\hline & $\begin{array}{l}\text { Eicosapentaenoyl dopamine } \\
\text { (EPADA) }\end{array}$ & $\begin{array}{c}\text { (5Z,8Z,11Z,14Z,17)- } N \text { - } \\
\text { (3,4-Dihydroxyphenethyl)eicosa- } \\
\text { 5,8,11,14,17-pentaenamide }\end{array}$ & & [67] \\
\hline & $\begin{array}{c}\text { Docosahexaenoyl dopamine } \\
\text { (DHADA) }\end{array}$ & $\begin{array}{c}\text { (4Z,7Z,10Z,13Z,16Z,19Z)-N- } \\
\text { (3,4-Dihydroxyphenethyl) } \\
\text { docosa-4,7,10,13,16,19- } \\
\text { hexaenamide }\end{array}$ & & [67] \\
\hline & $\begin{array}{l}\text { Docosahexaenoyl serotonin } \\
\text { (DHA-5-HT) }\end{array}$ & $\begin{array}{l}\text { (4Z,7Z,10Z,13Z,16Z,19Z)-N- } \\
\text { [2-(5-hydroxy-1H-indol-3-yl)ethyl]- } \\
\text { docosa-4,7,10,13,16,19-hexaenamide }\end{array}$ & & [30] \\
\hline \multirow[t]{6}{*}{$\omega-6$ PUFAs } & $\begin{array}{l}\text { Linoleic acid (LA) } \\
\quad 18: 2(\omega-6)\end{array}$ & $\begin{array}{l}\text { (9Z,12Z)-Octadeca-9,12-dienoic } \\
\text { acid }\end{array}$ & & [68] \\
\hline & $\begin{array}{l}\text { 9-Hydroxyoctadecadienoic } \\
\text { acid(9-HODE) }\end{array}$ & $\begin{array}{c}(9 S, 10 E, 12 E)-9 \text {-Hydroxyoctadeca- } \\
\text { 10,12-dienoic acid }\end{array}$ & & {$[69,70]$} \\
\hline & $\begin{array}{c}\text { 13-Hydroxyoctadecadienoic } \\
\text { acid } \\
\text { (13-HODE) }\end{array}$ & $\begin{array}{c}\text { (9Z,11E,13S)-13-Hydroxyoctadeca- } \\
\text { 9,11-dienoic acid }\end{array}$ & & {$[69,70]$} \\
\hline & $\begin{array}{c}\text { 15-Deoxy- } \Delta-{ }^{12,14} \text {-prostaglandin } \\
\text { J2 (15d-PGJ2) }\end{array}$ & $\begin{array}{c}(Z)-7-((S, E)-5-((E) \text {-oct-2-en-1- } \\
\text { ylidene)-4-oxocyclopent-2-en-1-yl) } \\
\text { hept-5-enoic acid }\end{array}$ & & [71] \\
\hline & $(9 Z, 11 E)$-CLA & $\begin{array}{l}\text { (9Z,11E)-Octadeca-9,11-dienoic } \\
\text { acid }\end{array}$ & & [72] \\
\hline & $(9 E, 11 E)$-CLA & $\begin{array}{c}(9 E, 11 E) \text {-Octadeca-9,11-dienoic } \\
\text { acid }\end{array}$ & & [72] \\
\hline \multirow{2}{*}{$\begin{array}{l}\text { Conjugated linoleic } \\
\text { acid (CLA) }\end{array}$} & (9Z,11Z)-CLA & $\begin{array}{l}\text { (9Z,11Z)-Octadeca-9,11-dienoic } \\
\text { acid }\end{array}$ & & [72] \\
\hline & $(10 E, 12 E)-C L A$ & $\begin{array}{c}(10 E, 12 E) \text {-Octadeca-9,11-dienoic } \\
\text { acid }\end{array}$ & & [72] \\
\hline
\end{tabular}


Table 1. Cont.

\begin{tabular}{|c|c|c|c|c|}
\hline Class & Common Name & IUPAC NAME & Chemical Structure & References \\
\hline \multirow{2}{*}{ Nitrated fatty acids } & Nitrolinolenic acid & $\begin{array}{l}\text { (9Z,12Z)-2-Nitrooctadeca-9,12- } \\
\text { dienoic acid }\end{array}$ & & [60] \\
\hline & 10-Nitrooleic acid & (9Z)-10-Nitrooctadec-9-enoic acid & & [61] \\
\hline \multirow[t]{3}{*}{$\begin{array}{l}\text { Bioactive } \\
\text { compounds }\end{array}$} & Genistein & $\begin{array}{l}\text { 5,7-Dihydroxy-3-(4- } \\
\text { hydroxyphenyl)-4H-chromen-4-one }\end{array}$ & & [73] \\
\hline & Quercetin & $\begin{array}{l}\text { 2-(3,4-Dihydroxyphenyl)-3,5,7- } \\
\text { trihydroxy-4H-chromen-4-one }\end{array}$ & & [74] \\
\hline & Luteolin & $\begin{array}{l}\text { 2-(3,4-Dihydroxyphenyl)-5,7- } \\
\text { dihydroxy-4H-chromen-4-one }\end{array}$ & & [75] \\
\hline
\end{tabular}

${ }^{1}$ PUFAs: polyunsaturated fatty acids.

\subsection{Synthetic PPAR $\gamma$ Ligands}

Although several synthetic molecules have shown affinity for PPAR $\gamma$, TDZs represent the most important synthetic PPAR $\gamma$ ligands. These compounds, working as insulin sensitizers, are oral hypoglycemic agents suggested as second-line medication in the treatment of type 2 diabetes mellitus [76]. Troglitazone was the first TZD approved for clinical use, but it has been removed from the market in 2000 because of its liver toxicity. So far, Ciglitazone was never used as a medication, while rosiglitazone and pioglitazone are authorized for the treatment of type II diabetes as monotherapy or in combination with insulin, metformin or sulfonylurea, but their prescription and use are under several restrictions because of their potential side effects. Particularly, rosiglitazone was withdrawn from the market in Europe and in other several countries in 2010 because the benefits no longer outweighed the risks [77]. Edaglitazone is a potent and selective PPAR $\gamma$ agonist [78]. Recently, other two TDZ drugs, rivoglitazone and efatutazone, have been developed and are currently undergoing clinical trials [79,80]. The effects of TDZs depend on their ability to bind PPAR $\gamma$ and modulate PPAR $\gamma$ target gene expression through transactivation or transrepression mechanisms. Although the primary target tissue of TDZs is the adipose tissue, where PPAR $\gamma$ is most abundantly expressed, the hypoglycemic effects of TDZs depend on the insulin-stimulated glucose disposal in the skeletal muscle. However, the mechanism by which TDZs promote insulin action in nonadipocyte tissue is still unknown [35,81,82]. Despite TDZs are well tolerated, their administration may be responsible for a range of side effects, including edema, anemia, weight gain, and increased incidence of cardiovascular diseases [83]. In order to reduce the side effects of TDZ, partial PPAR $\gamma$ agonists, named "selective PPAR $\gamma$ modulators" (SPPARMs), have been developed, but they are not currently used in clinical practice $[35,84,85]$. In addition to TDZs, nonsteroidal anti-inflammatory drugs (NSAIDs) have been described as PPAR $\gamma$ agonists [86]. Recently, it has been demonstrated that NSAIDs, including sulindac sulfide, diclofenac, indomethacin, and ibuprofen, show different affinity to PPAR $\gamma$ and modulate its activity at pharmacological concentration, but the research in this direction is largely missing [87]. The most common synthetic PPAR $\gamma$ ligands are reported in Table 2. 
Table 2. Class, common as well as IUPAC name, and chemical structure of synthetic PPAR $\gamma$ ligands.

\begin{tabular}{|c|c|c|c|c|}
\hline Class & Common Name & IUPAC Name & Chemical Structure & References \\
\hline $\mathrm{TDZs}^{1}$ & Troglitazone & $\begin{array}{l}\text { 5-[[4-[(6-Hydroxy-2,5,7,8- } \\
\text { tetramethyl-3,4-dihydrochromen- } \\
\text { 2-yl)methoxy]phenyl]methyl]-1,3- } \\
\text { thiazolidine-2,4-dione }\end{array}$ & & [88] \\
\hline & Ciglitazone & $\begin{array}{l}\text { 5-\{4-[(1-Methylcyclohexyl)methoxy] } \\
\text { benzyl\}-1,3-thiazolidine-2,4-dione }\end{array}$ & & [89] \\
\hline & Pioglitazone & $\begin{array}{l}\text { 5-[[4-[2-(5-Ethylpyridin-2-yl)ethoxy] } \\
\text { phenyl]methyl]-1,3-thiazolidine- } \\
\text { 2,4-dione }\end{array}$ & & [90] \\
\hline & Rosiglitazone & $\begin{array}{l}\text { 5-(4-(2-(Methyl(pyridin-2-yl)amino) } \\
\text { ethoxy)benzyl)thiazolidine-2,4-dione }\end{array}$ & & [91] \\
\hline & Edaglitazone & $\begin{array}{l}\text { 5-[[4-[2-(5-Methyl-2-phenyl-1,3- } \\
\text { oxazol-4-yl)ethoxy]-1- } \\
\text { benzothiophen-7-yl]methyl]-1,3- } \\
\text { thiazolidine-2,4-dione }\end{array}$ & & [78] \\
\hline & Efatutazone & $\begin{array}{l}\text { 5-[(4-\{[6-(4-Amino-3,5- } \\
\text { dimethylphenoxy)-1-methyl-1H- } \\
\text { 1,3-benzodiazol-2-yl]methoxy\} } \\
\text { phenyl)methyl]-1,3-thiazolidine- } \\
\text { 2,4-dione }\end{array}$ & & [80] \\
\hline & Rivoglitazone & $\begin{array}{l}\text { 5-(\{4-[(6-Methoxy-1-methyl-1H- } \\
\text { benzimidazol-2-Yl)methoxy] } \\
\text { phenyl\}methyl)-1,3-thiazolidine- } \\
\text { 2,4-dione }\end{array}$ & & [79] \\
\hline \multirow{4}{*}{ SPPARMs $^{2}$} & GW0072 & $\begin{array}{l}\text { 3-(4-(4-Carboxyphenyl)butyl)-2- } \\
\text { heptyl-4-oxo-5-thiazolidine }\end{array}$ & & [92] \\
\hline & Fmoc-L-leucine & $\begin{array}{l}\text { 2-(9H-Fluoren-9- } \\
\text { ylmethoxycarbonylamino)-4- } \\
\text { methylpentanoic acid }\end{array}$ & & [93] \\
\hline & Balaglitazone & $\begin{array}{l}\text { 5-(4-((3-Methyl-4-oxo-3,4- } \\
\text { dihydroquinazolin-2-yl)methoxy) } \\
\text { benzyl)thiazolidine-2,4-dione }\end{array}$ & & [94] \\
\hline & Netoglitazone & $\begin{array}{l}\text { 5-[[6-[(2-Fluorophenyl)methoxy] } \\
\text { naphthalen-2-yl]methyl]-1,3- } \\
\text { thiazolidine-2,4-dione }\end{array}$ & & [95] \\
\hline
\end{tabular}


Table 2. Cont.

\begin{tabular}{|c|c|c|c|c|}
\hline Class & Common Name & IUPAC Name & Chemical Structure & References \\
\hline \multirow{4}{*}{ NSAIDs $^{3}$} & Sulindac sulfide & $\begin{array}{l}\text { 5-Fluoro-2-methyl-1-[ } p \text {-(methylthio) } \\
\text { benzylidene]indene-3-acetic acid }\end{array}$ & & [87] \\
\hline & Diclofenac & $\begin{array}{l}\text { 2-[2-(2,6-Dichloroanilino)phenyl] } \\
\text { acetic acid }\end{array}$ & & [87] \\
\hline & Indomethacin & $\begin{array}{l}\text { 2-[1-(4-Chlorobenzoyl)-5-methoxy-2- } \\
\text { methylindol-3-yl]acetic acid }\end{array}$ & & {$[68,84,87]$} \\
\hline & Ibuprofen & 2-(4-Isobutylphenyl)propanoic acid & & [87] \\
\hline
\end{tabular}

${ }^{1}$ TDZs: thiazolidinediones; ${ }^{2}$ SPPARMs: selective PPAR $\gamma$ modulators; ${ }^{3}$ NSAIDs: nonsteroidal anti-inflammatory drugs.

\section{The Role of the PPAR $\gamma$ Ligands in Breast Cancer}

Since different cell lines, including breast, prostate, colon, bladder, and thyroid cancer cells express high levels of PPAR $\gamma$, the potential role of PPAR $\gamma$ agonists in modulating cancer progression has been widely investigated [96,97]. A vast scientific literature about the effects of PPAR $\gamma$ agonists in breast cancer is currently available, reflecting the interest in the use of PPAR $\gamma$ ligands in breast cancer management. In the following sections, the recent knowledge regarding the effects of PPAR $\gamma$ agonists in breast cancer biology from in vitro experiments to in vivo and clinical studies will be discussed.

\subsection{In Vitro Studies}

Many investigations undertaken with the aim of assessing a direct effect of PPAR $\gamma$ agonists on different processes involved in breast carcinogenesis demonstrated that these molecules induce cell growth inhibition, trigger cell death, inhibit breast cancer cell motility, and invasion. Moreover, activated PPAR $\gamma$ may cross-talk with other signal transduction pathways antagonizing breast tumor proliferation.

\subsubsection{Regulation of Cell Growth and Cell Cycle}

Uncontrolled cell proliferation is a hallmark of cancer cells based on the deregulated activity of cell cycle proteins $[98,99]$. Cyclin-dependent kinases (CDKs) and their regulatory subunits, namely, cyclins, represent the major regulators of the cell cycle. By binding to the cyclins, CDKs control the transition of the cell cycle through the four sequential phases, G1, S, G2, and M phases. Their activity is tightly regulated by CDK inhibitors, such as $\mathrm{p} 21(\mathrm{CIP} 1 / \mathrm{WAF} 1)$ and phosphorylated retinoblastoma $(\mathrm{pRb})$, to prevent abnormal proliferation [100-102]. Cancer cells are frequently characterized by deregulated CDK-cyclin complex activities, resulting in prolonged proliferation or inappropriate re-entry into the cell cycle [100]. It has been reported that natural and synthetic PPAR $\gamma$ ligands reduce cancer cell proliferation controlling the protein expression of several cell cycle regulators [103]. Additionally, 15d-PGJ2, rosiglitazone, and troglitazone decrease the gene expression of cyclin D1 inducing G1 cell cycle arrest [71,104]. Particularly, 15d-PGJ2 represses the cyclin D1 gene transcription reducing the binding of p300 to c-Fos for the cyclin D1 promoter activity, without affecting the expression of the 
CDK4 [71]. In contrast, troglitazone regulates the expression of cyclin D1 as well as the expression and the activity of CDK4 and CDK2, attenuating the Rb hyperphosphorylation, which is required for the G1-S phase cell cycle transition [104]. Rosiglitazone also promotes G0-G1 cell cycle arrest in breast cancer cells upregulating p53 protein expression and its effector p21 in a PPAR $\gamma$-dependent manner [91]. Interestingly, the antiproliferative effects of PPAR $\gamma$ ligands are stronger in TNBC cells compared to ER $\alpha$-positive breast cancer cells [105], addressing that PPAR $\gamma$ agonists could be a good therapeutic tool for the management of the more aggressive breast cancer subtypes. However, it has been demonstrated that PPAR $\gamma$ ligands can improve the efficacy of antitumoral drugs in ER $\alpha$-positive breast cancer cells. Troglitazone has been demonstrated to exert a synergistic effect with tamoxifen in inducing growth inhibition, cell cycle arrest, and apoptosis in ER $\alpha$-positive MCF-7 breast cancer cells. Indeed, the combined treatment of troglitazone $(25 \mu \mathrm{M})$ with different doses of the selective estrogen receptor modulator tamoxifen $(0-5 \mu \mathrm{M})$ induces an increase in the percentage of cells in cell cycle arrest at G1-S phases and a stronger downregulation of cyclin D1 expression than in cells treated with tamoxifen alone [105]. However, the clinical value of these results is still under investigation. Some of the molecular mechanisms by which PPAR $\gamma$ ligands regulate cell growth and cell cycle are depicted in Figure 2.

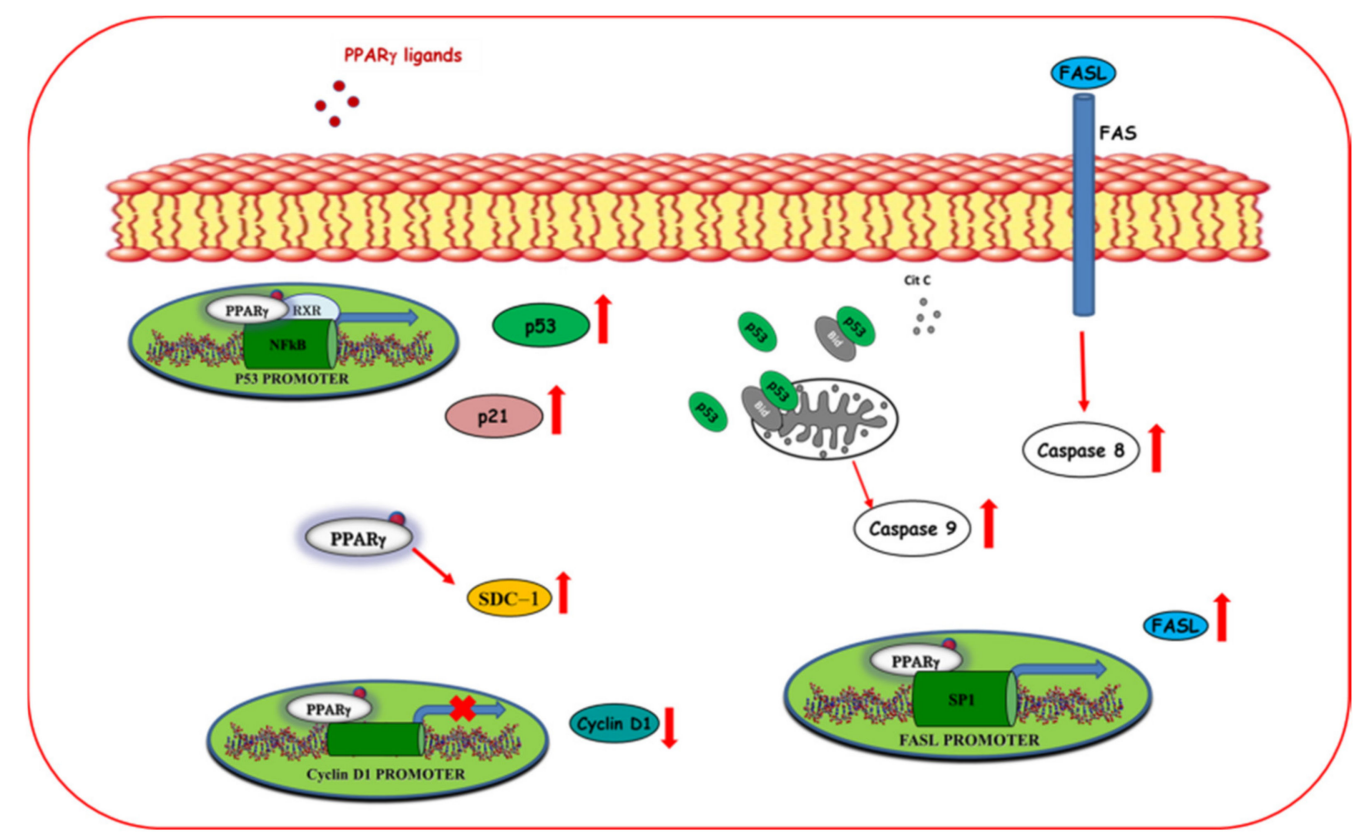

Figure 2. Molecular mechanisms by which ligand-activated PPAR $\gamma$ influences cell cycle and exerts proapoptotic effects in breast cancer cells. PPAR $\gamma$ ligands trans repressing the cyclin D1 promoter activity reduce its expression thereby inducing cell cycle arrest. Moreover, ligand activated PPAR $\gamma$ transactivates promoter gene $\mathrm{p} 53$ and enhances $\mathrm{p} 53$ protein expression and its target gene $\mathrm{p} 21$ triggering the intrinsic apoptotic pathways. In addition, PPAR $\gamma$ ligands upregulate the expression of syndecan-1 (SDC-1), inducing apoptosis. PPAR $\gamma$ ligands also trigger extrinsic apoptosis through activation of FAS ligand (FASL) gene promoter activity.

\subsubsection{Regulation of Cell Death}

Cancer cells residing in a transient (quiescence) or permanently (senescence) cell cycle arrested state represent a double-edged sword for tumor progression since both quiescent and senescent cells might promote cancer stemness and chemoresistance [106]. Interestingly, besides inducing cell cycle arrest, PPAR $\gamma$ ligands can promote breast cancer cell death through apoptosis or autophagy. 
Apoptosis

Apoptosis is a programmed cell death that occurs through two different pathways, namely, extrinsic and intrinsic pathways. Each pathway is initiated by the cleavage of caspases and carries on with a cascade of molecular events that determine the formation and degradation of apoptotic bodies $[107,108]$. Although the molecular mechanisms by which PPAR $\gamma$ ligands promote apoptosis are not fully understood, it has been reported that PPAR $\gamma$ agonists can trigger the two main signaling pathways of programmed cell death (Figure 2). In addition, 15d-PGJ2 induces apoptosis through mitochondrial dysfunction and reactive oxygen species (ROS) production, resulting in the activation of the extrinsic pathways [109]. Moreover, 15d-PGJ2 can also activate the intrinsic pathway, stimulating the release of the cytochrome $c$ from the mitochondria into the cytoplasm and the cleavage of caspase 3,7 and poly (ADP-ribose) polymerase (PARP) [109]. However, the activation of the intrinsic pathway is not essential for the effects of 15dPG-J2 on breast cancer cell apoptosis since the treatment with the caspase inhibitor N-benzoylcarbanyl-Val-Ala-Asp-fluoro methylketone (zVAD-fmk) or the overexpression of B-cell lymphoma-2 (Bcl-2) in MCF-7 cells did not abrogate the 15d-PGJ2-induced cell death [109]. Moreover, the involvement of PPAR $\gamma$ in mediating these apoptotic effects has not been fully clarified. Recently, it has been reported that the biotinylated form of 15d-PGJ2 showed a stronger effect in inducing cell growth inhibition and apoptosis compared to 15d-PG]2 [110]. Natural PPAR $\gamma$ ligands, including the $\omega-3$ PUFAs and their conjugates, revealed proapoptotic effects through the activation of $\operatorname{PPAR} \gamma[22,67,111]$. It has been demonstrated that DHA induces apoptosis through the up-regulation of the tumor suppressor molecule syndecan-1 (SDC-1) in a PPAR $\gamma$-dependent manner in MCF-7 cells [22]. Moreover, Rovito and coworkers have demonstrated that long-term treatment with the conjugates of EPA and DHA with dopamine (DA), EPADA, and DHADA, respectively, induced apoptosis in different human breast cancer cell lines, including MCF-7 (ER $\alpha$ positive), SKBR3 (ER/PR double negative and HER2 overexpressing), and MDA-MB-231 (triple negative) cells after the blockade of the autophagic flux. Indeed, treatment with EPADA and DHADA for $48 \mathrm{~h}$ increases the expression of p62, which expression levels inversely correlate with autophagic activity, and enhances the cleavage of both beclin-1 and caspase 9, suggesting the inhibition of the autophagy and the induction of intrinsic apoptosis [67]. Interestingly, it has been demonstrated that the proapoptotic effects of PPAR $\gamma$ ligands in breast cancer cells can be improved though multidrug approaches. Hydralazine, a drug used in the treatment of cardiovascular disease, has been found to boost the antiproliferative and proapoptotic effects of rosiglitazone in MDA-MB-231 cells. Although the molecular mechanism responsible for this effect is not fully understood, Jiang and coworkers suggested that hydralazine might reduce the hypermethylation of PPAR $\gamma$ preventing its inactivation [112]. Ciglitazone has been demonstrated to exert a synergic effect with a selective cyclooxygenase-2 (COX-2) inhibitor in inducing growth inhibition and apoptosis [113]. In addition, the combination of troglitazone with different RXR agonists has been demonstrated to induce growth inhibition in different cell lines and apoptosis in breast cancer cells [114]. Moreover, our research group has reported that low concentrations of rosiglitazone and the RXR ligand 9-cis-retinoic acid (9RA) induce the intrinsic apoptotic pathway in breast cancer cells through both dependent or independent p53 transcriptional activity [44,45]. Indeed, the combination of these drugs transactivates the tumor suppressor p 53 promoter gene and enhances p53 protein expression and its target gene $\mathrm{p} 21$, increasing the release of the cytochrome $\mathrm{c}$ from the mitochondria into the cytoplasm and the cleavage of caspase-9 [44]. Interestingly, RXR and PPAR $\gamma$ agonists can also activate the intrinsic apoptosis through the upregulation of the proapoptotic Bid and the formation of a p53-Bid complex at the mitochondria promoting apoptosis [45]. Finally, it has been also demonstrated that PPAR $\gamma$ activated by rosiglitazone triggers extrinsic apoptotic process via a direct involvement of FAS/FAS ligand (FASL) signaling pathway. This occurs by PPAR $\gamma$ binding to the Sp1 sequence located within the FASL gene promoter leading to an upregulation of FASL expression, which causes caspase 8 cleavage and apoptotic cell death [115]. 
Autophagy

Autophagy is a highly preserved catabolic process consisting of the degradation of intracellular components in order to maintain cell homeostasis [116]. Cellular stresses, such as starvation, stimulate the activation of the autophagic flux, which leads to the formation of the autophagosome and the degradation of its cargo after fusion with the lysosomes [117]. It has been demonstrated that $\operatorname{PPAR} \gamma$ ligands trigger autophagy, which can precede and facilitate the activation of apoptotic cell death in breast cancer cells (Figure 3).

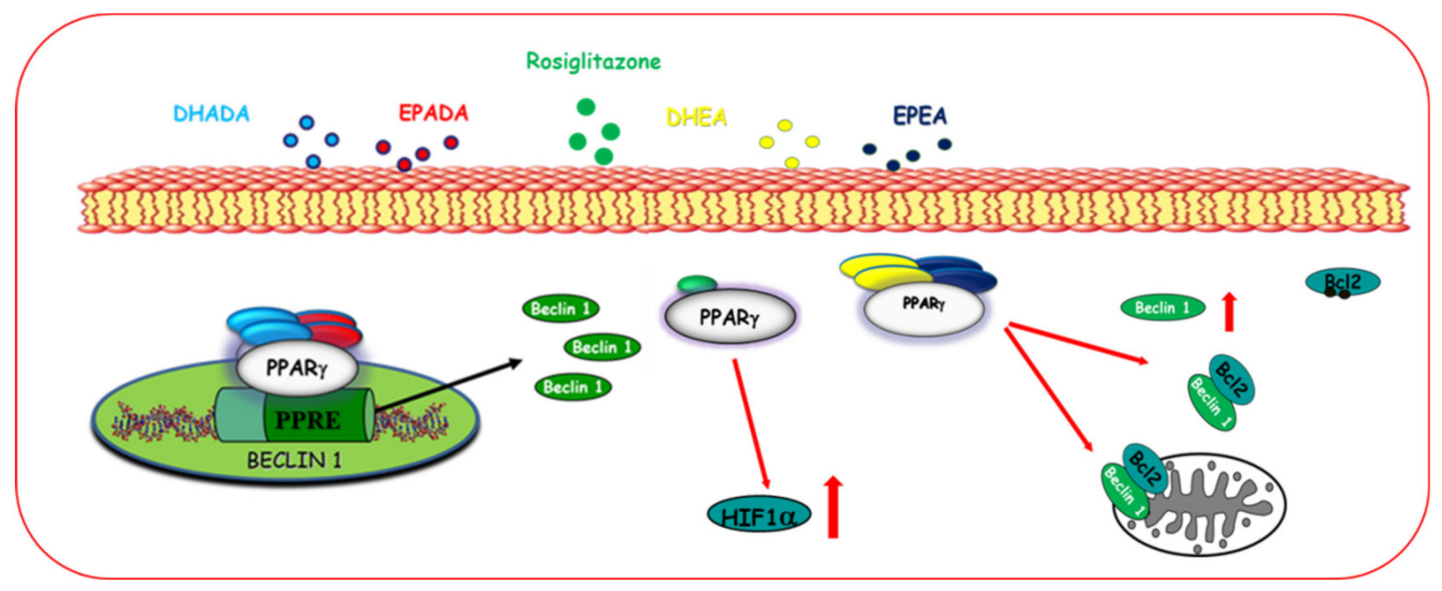

Figure 3. Activation of PPAR $\gamma$ induces autophagy in breast cancer cells. Natural and synthetic PPAR $\gamma$ increase hypoxia-inducible factor $1(\mathrm{HIF} 1 \alpha)$ and Beclin-1 expression, which also results from the dissociation of the Beclin-1/Bcl2 complex thereby inducing autophagy.

Zhou and coworkers found that troglitazone and rosiglitazone stimulate autophagy in triple-negative MDA-MB-231 breast cancer cells in a PPAR $\gamma$-dependent manner through the upregulation of the hypoxia-inducible factor 1 (HIF1 $\alpha$ ), which is required for the hypoxia-induced autophagy [88]. Moreover, Rovito and coworkers have described that different conjugates of $\omega-3$ PUFAs induce autophagy in breast cancer cells through PPAR $\gamma$ activation [21]. In particular, the conjugates of EPA and DHA with ethanolamine, EPEA and DHEA, respectively, promote the dissociation of the Beclin-1/Bcl2 complex, thus increase Beclin-1, which is crucial to induce autophagy. Moreover, EPEA and DHEA treatment reduces the phosphorylation of $\mathrm{p} 38$ and enhances the microtubule-associated protein light chain 3 (LC-3) levels, a specific membrane marker for the detection of early autophagosome formation [21]. Other two $\omega-3$ PUFA derivatives, EPADA and DHADA, are able to induce autophagy as the first early event of PPAR $\gamma$-dependent cell death. This event occurs by upregulating Beclin-1 transcriptional activity, which involves either PPAR $\gamma$ and RXR activation [67].

\subsubsection{Regulation of Motility and Invasion}

Breast cancer mortality mainly occurs because of the ability of cancer cells to metastasize to other sites. Breast cancer cell migration and invasion from the origin site to other second organs, including bone, lung, liver, and brain, represent the first steps of metastasis. PPAR $\gamma$ ligands have been found to counteract cell migration and invasion regulating the secretion of soluble factors and the chemokine networks in the tumor microenvironment (Figure 4).

In particular, it has been reported that non-toxic doses of 15d-PGJ2, DHA, and troglitazone reduce breast cancer cell invasion through the downregulation of the matrix metalloproteinases-9 (MMP9), a protease implicated in the extracellular matrix degradation in MCF-7 breast cancer cells [118-120]. The molecular mechanism by which PPAR $\gamma$ activated by ligands inhibits MMP9 expression occurs through suppression of 12-O-Tetradecanoylphorbol-13-acetate (TPA)-induced NF- $\mathrm{kB}$ sequence within MMP9 promoter [118]. Moreover, it has been described that rosiglitazone can block migration and invasion in breast cancer cells through the downregulation of CXCR4, one of the most important 
receptors involved in these processes [39]. Particularly, PPAR $\gamma$ directly binds to a newly identified PPRE-like sequence present in the CXCR4 promoter gene [39]. Interestingly, rosiglitazone also decreases the expression of CXCR4 in CAFs, which represent the principal source of stromal cell-derived factor 1 $($ SDF-1 $\alpha$ ) production, inhibiting their migratory capabilities and interfering with the autocrine and paracrine signaling loop acting to sustain breast tumor progression [39].

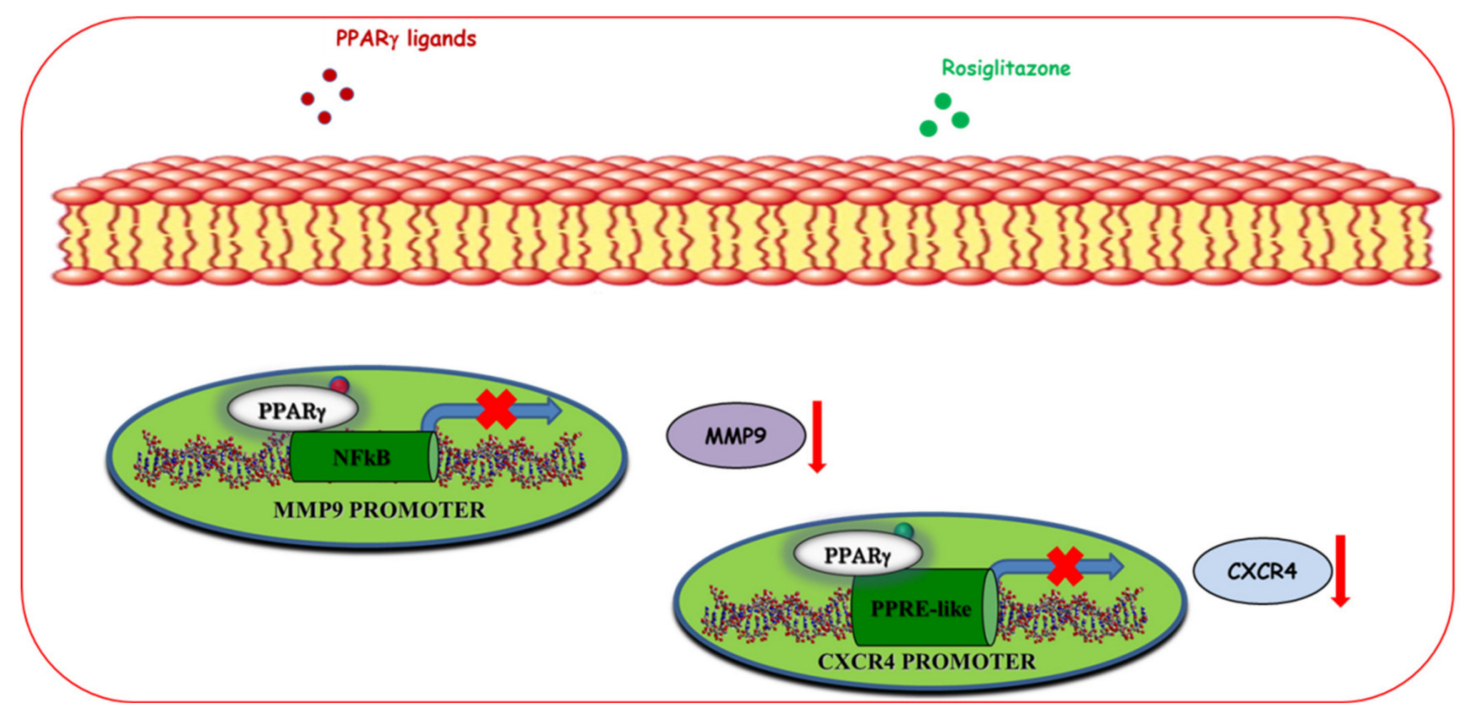

Figure 4. Ligand-activated PPAR $\gamma$ modulates motility and invasion of breast cancer cells. PPAR $\gamma$ agonists, through downregulation at transcriptional level of matrix metalloproteinases-9 (MMP-9) and C-X-C chemokine receptor type 4 (CXCR4), reduce both protein expression and inhibit breast cancer motility and invasion.

\subsubsection{Cross-Talk of PPAR $\gamma$ with Other Signal Transduction Pathways}

PPAR $\gamma$ agonists, other than their direct action through own receptor, can interfere with other signaling pathways, including ER $\alpha$, HER2/HER3, and leptin (Figure 5).

It has been reported that a dual regulation occurs between ER $\alpha$ and PPAR $\gamma$ pathways. Indeed, ligand-activated PPAR $\gamma$ can bind to estrogen-responsive element (ERE) blocking the transcription of the ER $\alpha$ target genes [121], whereas ER $\alpha$ negatively interferes with PPRE-mediated transcriptional activity [122]. It has also been found that ER $\alpha$ binds to PPRE sequence sharing with PPAR $\gamma$, the capability to bind AGGTCA half site contained in PPRE and ERE sequences [123]. Moreover, $\mathrm{ER} \alpha$ physically interacts with PPAR $\gamma$ in a multiprotein complex involving p85, the regulatory subunit of the phosphatidylinositol 3-kinase (PI3K) survival pathway, even though ligand-activated PPAR $\gamma$, exerting an opposite effect on the PI3K/AKT transduction pathway compared to ER $\alpha$, induces breast cancer cell growth inhibition. Interestingly, the antiproliferative effects exerted by PPAR $\gamma$ ligands can be potentiated in the presence of specific ER $\alpha$ antagonists, supporting the potential role of PPAR $\gamma$ ligands in multidrug regimens for the treatment of hormone-positive breast cancer [123]. It has been reported that PPAR $\gamma$ ligands can also modulate the estrogen synthesis. In particular, troglitazone and 15d-PGJ2 were able to reduce the aromatase expression in breast adipose stromal cells treated with oncostatin $\mathrm{M}$ or tumor necrosis factor (TNF) $\alpha$ and dexamethasone in a concentration-dependent manner, thus blocking the conversion of androgens to estrogens [124]. Moreover, Pignatelli and coworkers have described a cross-talk between PPAR $\gamma$ and the membrane tyrosine kinase receptor HER2/Erb signal, which is involved in breast cancer tumor progression. Indeed, 15d-PGJ2 inhibited the neuregulin-induced phosphorylation of HER2 and HER3, triggering apoptosis, cell growth inhibition, and differentiation [125]. In an in vitro and in vivo experimental approach, rosiglitazone antagonizes the proliferative effects exerted by leptin in breast cancer cells and abrogates the leptin-induced tumor growth in nude mice implanted with MCF-7 cells [126]. Specifically, the molecular mechanism by 
which rosiglitazone counteracts leptin action is related to the repression of leptin transcription via the recruitment of two PPAR $\gamma$ corepressors, N-CoR and SMRT, to the glucocorticoid-responsive element in the promoter region of the leptin. In addition, rosiglitazone reduces the expression of the leptin receptors, antagonizes the leptin signal, and inhibits the MAPK/STAT3/Akt pathway [126], suggesting that PPAR $\gamma$ agonists may have a potential role in the treatment of breast cancer patients.

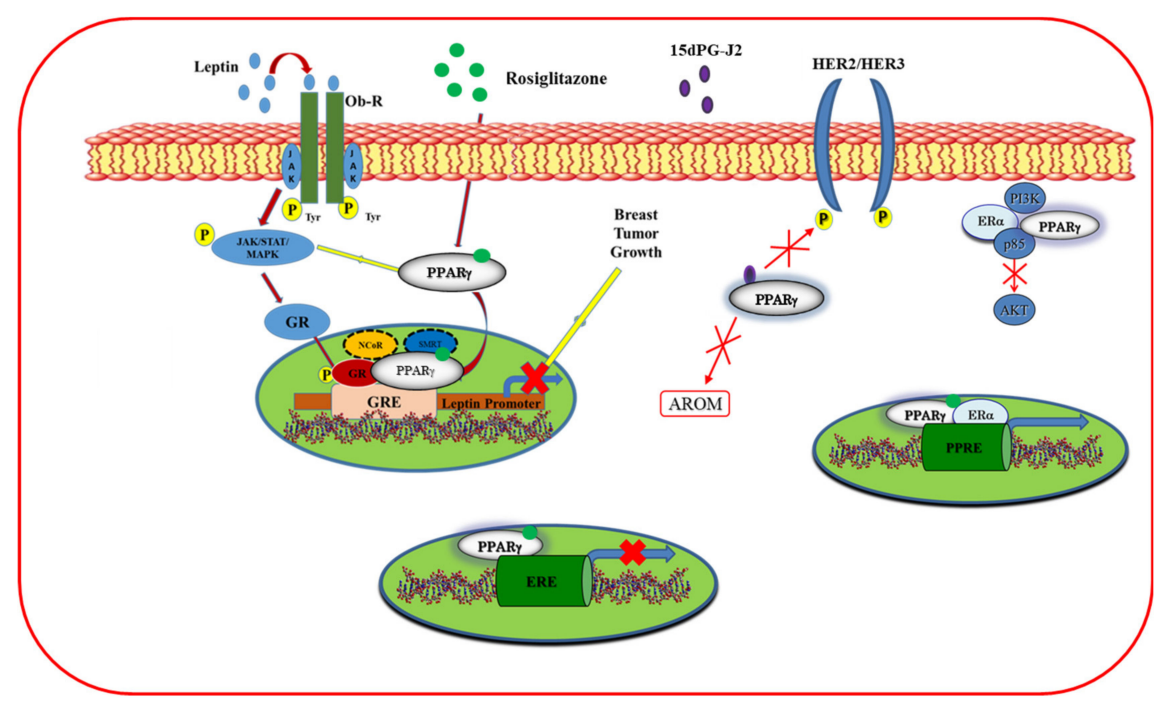

Figure 5. Cross-talk of PPAR $\gamma$ with other receptors in breast cancer cells. PPAR $\gamma$ ligands inhibit the leptin transcription and leptin-induced activation of JAK-STAT (Janus kinase/signal transducers and activators of transcription) and MAPK (mitogen-activated protein kinase) signaling. Moreover, ligand-activated PPAR $\gamma$ interferes with the human epidermal growth factor receptor 2/3 (HER2/HER3) pathway, decreases aromatase expression, trans represses the estrogen receptor $\alpha(E R \alpha)$ target genes, and interacts with ER $\alpha$ antagonizing the activation of survival phosphatidylinositol 3-kinase (PI3K)/AKT (protein kinase B) signaling cascade, thus regulating breast cancer proliferation.

\subsection{In Vivo Studies}

Although the importance of PPAR $\gamma$ expression in modulating in vivo breast tumor formation is still controversial [127], the effects of several PPAR $\gamma$ ligands in controlling breast carcinogenesis have been confirmed in animal models. Troglitazone alone or in combination with the RXR ligand all-trans-retinoic acid (ATRA) has been demonstrated to reduce the tumor size and weight in triple-immunodeficient mice inoculated with MCF-7 breast cancer cells, inducing tumor growth inhibition in vivo. Interestingly, troglitazone caused apoptotic effects in the tumors, without inducing toxic effects in the mice. However, more marked apoptotic changes were observed in mice treated with the combination of troglitazone and ATRA, confirming the ability of PPAR $\gamma$ agonists to exert synergistic effects with other compounds [128]. Moreover, MDA-MB-231 cells treated with 15d-PGJ2 prior to inoculation in BALB/C nude mice have demonstrated a decreased capability to form tumors compared to untreated control [129]. Rosiglitazone was also able to prevent the leptin-induced tumor growth in nude mice after 12 weeks of treatment [126]. Notably, the administration of rosiglitazone was well tolerated because no significant differences in the mean weights or in the histologic features of the major organs (liver, lung, spleen, and kidney) were observed between vehicle-treated mice and those that received treatment [126]. Moreover, a novel synthetic PPAR $\gamma$ ligand, the triterpenoid 2-Cyano-3,12-dioxooleana-1,9-dien-28-oic acid (CDDO), was found to lower the tumor growth of MDA-MB-435 breast cancer cells implanted in nude mice [130]. Suppression of tumor cell growth by $\omega-3$ PUFAs has been confirmed in vivo using cancer animal models mainly represented by xenograft nude mice implanted with different tumor cell types [131-135] and by transgenic rodent models [136-138]. Indeed, dietary supplementation with $\omega-3$ PUFAs has been reported to increase PPAR $\gamma$ protein expression, which was concomitant with a reduction of tumor burden in rats with induced mammary carcinogenesis [139]. All the above considerations support 
the opportunity of reaching therapeutic levels of these compounds in experimental in vivo models by dietary means as well as by the pharmacological use of receptor agonists to achieve potential anticancer benefits.

\subsection{Clinical Studies}

Despite the large number of preclinical studies investigating the role of ligand-activated PPAR $\gamma$ in breast cancer, only a few clinical trials have been conducted, and the results mainly address the potential of PPAR $\gamma$ agonists on breast cancer risk in healthy women and on the modulation of chemotherapy-related side effects in breast cancer patients. A phase II study of troglitazone was carried out in patients with advanced breast cancer refractory to hormonal and chemotherapy agents, but it demonstrated only a few clinical benefits. Indeed, only 3 of 21 enrolled patients showed a stable disease at 8 weeks, whereas no objective tumor responses or stabilization for 6 months were observed [19]. In contrast, a pilot trial of rosiglitazone in early-stage breast cancer patients revealed that the administration of rosiglitazone between the time of diagnostic biopsy and definitive surgery may be relevant for breast cancer treatment. Although rosiglitazone was not found to reduce breast tumor proliferation, it increased the serum adiponectin levels and reduced insulin resistance, which is correlated with breast cancer risk [140]. Till date, another clinical trial using synthetic PPAR $\gamma$ agonist rosiglitazone has been reported in the ClinicalTrials.gov databases, whereas 40 clinical studies have been conducted with dietary $\omega-3$ PUFAs in breast cancer. Interestingly, 17 clinical trials have been completed and mainly assessed the role of EPA and DHA in reducing breast cancer risk and controlling the side effects of chemotherapy thus impacting breast cancer survivors. Details of these studies are included in Table 3.

Table 3. List of the studies on PPAR $\gamma$ agonists and breast cancer at www.clinicaltrials.gov.

\begin{tabular}{|c|c|c|c|c|}
\hline NCT & Intervention/Treatment & Phase & $\begin{array}{l}\text { Eligibility Criteria, Primary Outcome and } \\
\text { Purpose }\end{array}$ & References \\
\hline NCT01282580 & $\begin{array}{l}\text {-Lovaza } \\
\text { - } \omega \text {-3 fatty acid capsules } \\
\text {-Dietary fish (canned } \\
\text { salmon, albacore) }\end{array}$ & I & $\begin{array}{l}\text { Eligibility criteria: female ( } \geq 18 \text { years) having } \\
\text { increased risk for breast cancer based on family } \\
\text { and personal history with a normal mammogram } \\
\text { in the past } 12 \text { years and }>1 \text { years from pregnancy, } \\
\text { lactation, or chemotherapy. Primary outcome: } \\
\text { fatty acid profiles of breast adipose tissue. } \\
\text { Purpose: to determine the effects of increased } \\
\text { fish consumption on serum and breast fat tissue } \\
\text { fatty acids and to assess adherence and } \\
\text { tolerability of increased dietary intake of fish } \\
\text { relative to an } \omega-3 \text { fatty acid supplement. }\end{array}$ & [141] \\
\hline NCT02150525 & $\begin{array}{l}-\omega-3 \text { fatty acids } \\
\text {-Placebo }\end{array}$ & II & $\begin{array}{l}\text { Eligibility criteria: postmenopausal women } \\
\text { ( } 45-65 \text { years) with a history of breast cancer after } \\
12 \text { months from surgery and } 3 \text { months from } \\
\text { completion of chemotherapy. Subjects must } \\
\text { present at least one symptom of atrophic } \\
\text { vaginitis. Primary outcome: improvement of } \\
\text { vaginitis' symptoms by oral } \omega-3 \text { fatty acids. } \\
\text { Purpose: to study the effectiveness of } \omega-3 \text { fatty } \\
\text { acid on atrophic vaginitis in postmenopausal } \\
\text { breast cancer patients. }\end{array}$ & NA \\
\hline NCT02101970 & $\begin{array}{l}\text {-Weight Loss }+\omega-3 \text { fatty } \\
\text { acids } \\
\text {-Weight Loss }+ \text { Placebo }\end{array}$ & NA & $\begin{array}{l}\text { Eligibility criteria: female having evidence of } \\
\text { hyperplasia with Masood score of } 13 \text { or higher, } \\
500 \text { or more epithelial cells on cytology slide of } \\
\text { screening random periareolar fine-needle } \\
\text { aspiration, and reasonable hematopoietic, kidney, } \\
\text { and liver function. Primary outcome: dropout } \\
\text { rate. Purpose: to determine if high dose } \\
\text { supplementation with the } \omega-3 \text { fatty acids EPA } \\
\text { and DHA, when added to a weight loss program, } \\
\text { is well tolerated and if there is an increase in the } \\
\text { favorable change in blood and tissue breast } \\
\text { cancer risk factors when compared to weight loss } \\
\text { alone. }\end{array}$ & NA \\
\hline
\end{tabular}


Table 3. Cont

\begin{tabular}{|c|c|c|c|c|}
\hline NCT & Intervention/Treatment & Phase & $\begin{array}{l}\text { Eligibility Criteria, Primary Outcome and } \\
\text { Purpose }\end{array}$ & References \\
\hline NCT02816125 & $\begin{array}{l}\text {-Diet supplemented with } \\
\text { EPA + DHA } \\
\text {-Dietary fat at less than } \\
20 \% \text { energy + EPA + } \\
\text { DHA }\end{array}$ & III & $\begin{array}{l}\text { Eligibility criteria: menstruating and } \\
\text { premenopausal women ( } \geq 18 \text { years). Primary } \\
\text { outcome: fatty acid incorporation into red blood } \\
\text { cells and in cell material from nipple aspirate } \\
\text { fluid. Purpose: to examine the effect of the } \\
\text { combined treatment with EPA and DHA on } \\
\text { breast cancer risk factors in healthy } \\
\text { premenopausal women. }\end{array}$ & [142] \\
\hline NCT00723398 & $\begin{array}{l}\text {-Raloxifene } \\
\text {-Lovaza } \\
\text {-Lovaza + Raloxifene }\end{array}$ & NA & $\begin{array}{l}\text { Eligibility criteria: no smoker postmenopausal } \\
\text { women ( } 35-70 \text { years) without hormone-replaced } \\
\text { therapy for at least } 6 \text { months. Primary outcome: } \\
\text { absolute breast density. Purpose: to evaluate the } \\
\text { effects of Raloxifene alone or in combination with } \\
\text { omega- } 3 \text { fatty acids on breast cancer } \\
\text { development markers in postmenopausal } \\
\text { women. }\end{array}$ & [143] \\
\hline NCT01823991 & $\begin{array}{l}\text {-Lovaza } \\
\text {-VitaBlue } \\
\text {-Placebo }\end{array}$ & Early I & $\begin{array}{l}\text { Eligibility criteria: women ( } 40-70 \text { years) having } \\
\text { stage II-IIIA of breast cancer after completion of } \\
\text { adjuvant treatment with chemo- and/or } \\
\text { radiotherapy in the past } 6 \text { months. Primary } \\
\text { outcome: cognitive function scores with } \\
\text { intervention. Purpose: to evaluate the safety of } \\
\text { nutritional intervention with n- } 3 \text { fatty acids and } \\
\text { blueberry anthocyanins on cognitive } \\
\text { performance. }\end{array}$ & NA \\
\hline NCT01869764 & $\begin{array}{l}-\omega-3 \text { fatty acids } \\
\text {-Placebo }\end{array}$ & II & $\begin{array}{l}\text { Eligibility criteria: newly diagnosed women } \\
\text { ( } \geq 18 \text { years) having in situ carcinoma and stage I } \\
\text { to III of breast cancer that will receive breast } \\
\text { surgery at least after } 7 \text { days from the day of } \\
\text { enrollment. Tumor size of at least } 1 \mathrm{~cm} \text {. Primary } \\
\text { outcome: } \omega-3 \text { fatty acid levels in breast tissues in } \\
\text { plasma and in erythrocytes before and after } \\
\text { surgery. Purpose: to study } \omega-3 \text { fatty acid effects } \\
\text { in patients with breast cancer. }\end{array}$ & NA \\
\hline NCT01385137 & $\begin{array}{l}\text { - } w \text {-3-fatty acids } \\
\text {-Placebo }\end{array}$ & III & $\begin{array}{l}\text { Eligibility criteria: postmenopausal women } \\
\text { with estrogen-receptor positive and/or } \\
\text { progesterone-receptor positive invasive breast } \\
\text { adenocarcinoma (I-IIIA stage) currently taking a } \\
\text { third-generation aromatase inhibitor; patients } \\
\text { must be subjected to modified radical } \\
\text { mastectomy or breast-sparing surgery. Primary } \\
\text { outcome: Brief Pain Inventory (BPI) Worst } \\
\text { Pain/Stiffness Score. Purpose: to study } \omega-3 \text { fatty } \\
\text { acid effects in muscle, bone pain, and stiffness in } \\
\text { breast cancer patients receiving hormone therapy. }\end{array}$ & [145] \\
\hline NCT01252277 & -Lovaza & II & $\begin{array}{l}\text { Eligibility criteria: premenopausal female } \\
\text { (18-54 years) having a breast cancer risk } \\
\text { evaluated on the basis of several criteria. } \\
\text { Primary outcome: proportion of subjects that } \\
\text { complete an intervention. Purpose: to evaluate } \\
\text { the effects of Lovaza on breast cancer biomarkers } \\
\text { in premenopausal patients. }\end{array}$ & [146] \\
\hline
\end{tabular}


Table 3. Cont

\begin{tabular}{|c|c|c|c|c|}
\hline NCT & Intervention/Treatment & Phase & $\begin{array}{l}\text { Eligibility Criteria, Primary Outcome and } \\
\text { Purpose }\end{array}$ & References \\
\hline NCT00627276 & - $\omega-3$ fatty acids-Placebo & NA & $\begin{array}{l}\text { Eligibility criteria: breast cancer patients having } \\
\text { confirmed diagnosis of ductal carcinoma in situ } \\
\text { and/or atypical ductal hyperplasia. Primary } \\
\text { outcome: genetic evaluation of markers for } \\
\text { breast cancer risk and progression, fatty acids } \\
\text { profile, occurrence of ductal carcinoma in situ } \\
\text { and/or atypical ductal hyperplasia or invasive } \\
\text { cancer in tissue samples. Purpose: to study the } \\
\text { effects of } \omega-3 \text { fatty acids in patients with ductal } \\
\text { carcinoma in situ and/or atypical ductal } \\
\text { hyperplasia. }\end{array}$ & NA \\
\hline NCT01824498 & $\begin{array}{l}\text {-Low-fat diet } \\
\text {-Low fat with high } \omega \\
\text {-3 diet-High-fat diet }\end{array}$ & NA & $\begin{array}{l}\text { Eligibility criteria: postmenopausal women } \\
\text { ( } 45-70 \text { years) having BMI between } 19 \text { and } 29 . \\
\text { Consumption of a "typical" American diet. } \\
\text { Primary outcome: plasma sex hormone levels, } \\
\text { Estradiol. Purpose: to determine whether diets } \\
\text { designed to increase plasma } \omega-3 \text { concentrations } \\
\text { will favorably affect sex hormone distribution in } \\
\text { women in a direction associated with reduced } \\
\text { risk of sex hormone-mediated cancer } \\
\text { development. }\end{array}$ & [148-151] \\
\hline NCT02062255 & $\begin{array}{l}\text {-Aspirin } \\
-\omega-3 \text { EPA and DHA } \\
\text {-Aspirin }+\omega-3 \text { EPA and } \\
\text { DHA }\end{array}$ & Early phase I & $\begin{array}{l}\text { Eligibility criteria: postmenopausal women } \\
\text { ( } \geq 18 \text { years). Primary outcome: prostaglandin E2, } \\
\text { aromatase, pro-inflammatory cytokines, steroids, } \\
\text { and lipids. Purpose: to study the impact of } \\
\text { COX2 on sera biomarkers from obese subjects. }\end{array}$ & NA \\
\hline NCT01821833 & $\begin{array}{l}-\omega-3 \text { fatty acids }+ \\
\text { paclitaxel } \\
- \text { Placebo }+ \text { paclitaxel }\end{array}$ & NA & $\begin{array}{l}\text { Eligibility criteria women ( } \geq 18 \text { years) with } \\
\text { breast cancer or ovarian cancer who will receive } \\
\text { paclitaxel treatment at least for } 2 \text { months. } \\
\text { Primary outcome: mean severity of pain. } \\
\text { Purpose: to study the effects of } \omega-3 \text { fatty acids } \\
\text { on pain of cancer patients. }\end{array}$ & NA \\
\hline NCT01902745 & $\begin{array}{l}\text {-Fatigue-reduction diet } \\
\text { (typical caloric intake } \\
\text { and replacement of some } \\
\text { calories with the } \\
\text { following foods: whole } \\
\text { grains, vegetables, fruit, } \\
\text { fatty fish, and nuts } \\
\text { and/or seeds) }\end{array}$ & NA & $\begin{array}{l}\text { Eligibility criteria: breast cancer patients }(\geq 18 \\
\text { years) having completed the cancer-related } \\
\text { treatments and showing persistent, moderate, or } \\
\text { severe fatigue despite standard treatment. } \\
\text { Primary outcome: fatigue in breast cancer } \\
\text { survivors. Purpose: to expand the data on } \\
\text { fatigue-reduction diet in breast cancer survivors }\end{array}$ & [153] \\
\hline NCT00933309 & $\begin{array}{l}\text {-Exemestane } \\
\text {-Exemestane }+ \\
\text { Avandamet } \\
\text { (rosiglitazone and } \\
\text { metformin) }\end{array}$ & I & $\begin{array}{l}\text { Eligibility criteria: postmenopausal women } \\
\text { with BMI } \geq 25 \mathrm{~kg} / \mathrm{m}^{2} \text { having estrogen receptor } \\
\text { positive and/or progesterone receptor positive } \\
\text { breast cancer along with clinical evidence of } \\
\text { metastasis. Primary outcome: Dose-limiting } \\
\text { toxicity (DLT). Purpose: to define the highest } \\
\text { tolerable dose of Avandamet in combination with } \\
\text { exemestane in postmenopausal obese breast } \\
\text { cancer patients. }\end{array}$ & [154] \\
\hline
\end{tabular}

\section{Conclusions}

Although substantial advances have been made in breast cancer diagnosis and treatment over the last years, this disease remains a major health problem among women worldwide. Despite limited in perspective, the overall suggestions from accumulated data relating to PPAR $\gamma$ and breast cancer strongly highlight that this receptor may have an important role as tumor suppressor. Hence, numerous preclinical studies indicate the ability of natural as well as synthetic PPAR $\gamma$ ligands to modulate 
the tumor cell signaling mechanisms and/or the cross-talk with various extracellular factors and intracellular pathways controlling the growth, survival, and invasive/metastatic behavior of breast cancer cells. Evidence also support that PPAR $\gamma$ activation results in inhibition of breast tumor growth either in vivo models or in vitro breast cancer cells. Despite these promising preclinical results, the published clinical studies on synthetic PPAR $\gamma$ ligands in breast cancer patients are limited and generally disappointing for their potential side effects. In this scenario, understanding the mechanism of action of natural compounds, such as $\omega-3$ PUFAs, could be useful for the development of new pharmacological tools in breast cancer. Moreover, one of the future priorities for a rational use of PPAR $\gamma$ agonists will be the identification of the subgroups of breast tumors currently lacking effective therapeutic options, which may really benefit from novel adjuvant therapeutic interventions. Finally, further investigation and additional clinical trials will confirm whether PPAR $\gamma$ agonists may represent a valuable tool in the prevention and treatment of breast cancer.

Author Contributions: Literature analysis, conceptualization, and artwork, G.A. and D.B.; original draft preparation and writing, G.A., C.G., L.G., I.B., S.C., and S.A.; artwork and editing, P.P.; review, supervision, and editing, D.B. All authors have read and agreed to the published version of the manuscript.

Funding: This work was supported by a special award to the Department of Pharmacy, Health and Nutritional Sciences of University of Calabria (Italy) (Department of Excellence, Italian Law 232/2016) from the Italian Ministry of Research and University (MIUR), by BANDO PRIN 2017 \#2017WNKSLR_005 to I.B. and \#2017EKMFTN_001 to S.C., by Fondazione AIRC: IG \#21414 to S.C., and by BANDO PRIN 2015 \#2015B7M39T to S.A.

Conflicts of Interest: The authors declare no conflict of interest.

\section{References}

1. Torre, L.A.; Islami, F.; Siegel, R.L.; Ward, E.M.; Jemal, A. Global cancer in women: Burden and trends. Cancer Epidemiol. Biomark. Prev. 2017, 26, 444-457. [CrossRef] [PubMed]

2. Bray, F.; Ferlay, J.; Soerjomataram, I.; Siegel, R.L.; Torre, L.A.; Jemal, A. Global cancer statistics 2018: GLOBOCAN estimates of incidence and mortality worldwide for 36 cancers in 185 countries. CA Cancer J. Clin. 2018, 68, 394-424. [CrossRef] [PubMed]

3. Waks, A.G.; Winer, E.P. Breast Cancer Treatment: A Review. JAMA 2019, 321, 288-300. [CrossRef] [PubMed]

4. Cho, S.-H.; Jeon, J.; Kim, S.I. Personalized Medicine in Breast Cancer: A Systematic Review. J. Breast Cancer 2012, 15, 265-272. [CrossRef]

5. Harbeck, N.; Penault-Llorca, F.; Cortes, J.; Gnant, M.; Houssami, N.; Poortmans, P.; Ruddy, K.; Tsang, J.; Cardoso, F. Breast cancer. Nat. Rev. Dis. Primers 2019, 5, 5-66. [CrossRef]

6. Anampa, J.; Makower, D.; Sparano, J.A. Progress in adjuvant chemotherapy for breast cancer: An overview. BMC Med. 2015, 13, 195. [CrossRef]

7. Weigelt, B.; Peterse, J.L.; Veer, L.J.V. Breast cancer metastasis: Markers and models. Nat. Rev. Cancer 2005, 5, 591-602. [CrossRef]

8. $\quad$ Chang-Qing, Y.; Jie, L.; Shi-Qi, Z.; Kun, Z.; Zi-Qian, G.; Ran, X.; Hui-Meng, L.; Ren-Bin, Z.; Gang, Z.; Yin, D.-C.; et al. Recent treatment progress of triple negative breast cancer. Prog. Biophys. Mol. Boil. 2020, 151, 40-53. [CrossRef]

9. Alasmael, N.; Mohan, R.; Meira, L.; Swales, K.E.; Plant, N. Activation of the Farnesoid X-receptor in breast cancer cell lines results in cytotoxicity but not increased migration potential. Cancer Lett. 2016, 370, 250-259. [CrossRef]

10. Garattini, E.; Bolis, M.; Garattini, S.K.; Fratelli, M.; Centritto, F.; Paroni, G.; Gianni', M.; Zanetti, A.; Pagani, A.; Fisher, J.N.; et al. Retinoids and breast cancer: From basic studies to the clinic and back again. Cancer Treat. Rev. 2014, 40, 739-749. [CrossRef]

11. Murray, A.; Madden, S.F.; Synnott, N.C.; Klinger, R.; O'Connor, D.P.; O’Donovan, N.; Gallagher, W.M.; Crown, J.; Duffy, M.J. Vitamin D receptor as a target for breast cancer therapy. Endocr.-Relat. Cancer 2017, 24, 181-195. [CrossRef]

12. Giordano, C.; Catalano, S.; Panza, S.; Vizza, N.; Barone, I.; Bonofiglio, D.; Gelsomino, L.; Rizza, P.; Fuqua, S.A.W.; Andò, S. Farnesoid X receptor inhibits tamoxifen-resistant MCF-7 breast cancer cell growth through downregulation of HER2 expression. Oncogene 2011, 30, 4129-4140. [CrossRef] 
13. Moseti, D.; Regassa, A.; Kim, W.K. Molecular Regulation of Adipogenesis and Potential Anti-Adipogenic Bioactive Molecules. Int. J. Mol. Sci. 2016, 17, 124. [CrossRef] [PubMed]

14. Kotta-Loizou, I.; Giaginis, C.; Theocharis, S. The role of peroxisome proliferator-activated receptor- $\gamma$ in breast cancer. Anti-Cancer Agents Med. Chem. 2012, 12, 1025-1044. [CrossRef] [PubMed]

15. Papadaki, I.; Mylona, E.; Giannopoulou, I.; Markaki, S.; Keramopoulos, A.; Nakopoulou, L. PPAR? expression in breast cancer: Clinical value and correlation with ER? Histopathology 2005, 46, 37-42. [CrossRef] [PubMed]

16. Jiang, Y.; Zou, L.; Zhang, C.; He, S.; Cheng, C.; Xu, J.; Lu, W.; Zhang, Y.; Zhang, H.; Wang, D.; et al. PPAR $\gamma$ and Wnt/ $\beta$-Catenin pathway in human breast cancer: Expression pattern, molecular interaction and clinical/prognostic correlations. J. Cancer Res. Clin. Oncol. 2009, 135, 1551-1559. [CrossRef]

17. Abduljabbar, R.; Alkaabi, M.; Negm, O.H.; Jerjees, D.; Muftah, A.A.; Mukherjee, A.; Lai, C.F.; Buluwela, L.; Ali, S.; Tighe, P.J.; et al. Prognostic and biological significance of peroxisome proliferator-activated receptor-gamma in luminal breast cancer. Breast Cancer Res. Treat. 2015, 150, 511-522. [CrossRef]

18. Chou, F.-S.; Wang, P.-S.; Kulp, S.; Pinzone, J.J. Effects of Thiazolidinediones on Differentiation, Proliferation, and Apoptosis. Mol. Cancer Res. 2007, 5, 523-530. [CrossRef]

19. Burstein, H.J.; Demetri, G.D.; Mueller, E.; Sarraf, P.; Spiegelman, B.M.; Winer, E.P. Use of the Peroxisome Proliferator-Activated Receptor (PPAR) $\gamma$ Ligand Troglitazone as Treatment for Refractory Breast Cancer: A Phase II Study. Breast Cancer Res. Treat. 2003, 79, 391-397. [CrossRef]

20. Fabian, C.J.; Kimler, B.F.; Hursting, S.D. Omega-3 fatty acids for breast cancer prevention and survivorship. Breast Cancer Res. 2015, 17, 62. [CrossRef]

21. Rovito, D.; Giordano, C.; Vizza, D.; Plastina, P.; Barone, I.; Casaburi, I.; Lanzino, M.; De Amicis, F.; Sisci, D.; Mauro, L.; et al. Omega-3 PUFA ethanolamides DHEA and EPEA induce autophagy through PPAR $\gamma$ activation in MCF-7 breast cancer cells. J. Cell. Physiol. 2013, 228, 1314-1322. [CrossRef] [PubMed]

22. Sun, H.; Berquin, I.M.; Owens, R.T.; O'Flaherty, J.T.; Edwards, I.J. Peroxisome proliferator-activated receptor gamma-mediated up-regulation of syndecan-1 by n-3 fatty acids promotes apoptosis of human breast cancer cells. Cancer Res. 2008, 68, 2912-2919. [CrossRef] [PubMed]

23. Berger, J.P.; Moller, D.E. The Mechanisms of Action of PPARs. Annu. Rev. Med. 2002, 53, 409-435. [CrossRef] [PubMed]

24. Fajas, L.; Fruchart, J.-C.; Auwerx, J. PPAR $\gamma 3$ mRNA: A distinct PPAR $\gamma$ mRNA subtype transcribed from an independent promoter. FEBS Lett. 1998, 438, 55-60. [CrossRef]

25. Beamer, B.A.; Negri, C.; Yen, C.-J.; Gavrilova, O.; Rumberger, J.M.; Durcan, M.J.; Yarnall, D.P.; Hawkins, A.L.; Griffin, C.A.; Burns, D.K.; et al. Chromosomal Localization and Partial Genomic Structure of the Human Peroxisome Proliferator Activated Receptor-Gamma (hPPAR $\gamma$ ) Gene. Biochem. Biophys. Res. Commun. 1997, 233, 756-759. [CrossRef] [PubMed]

26. Janani, C.; Kumari, B.R. PPAR gamma gene-A review. Diabetes Metab. Syndr. Clin. Res. Rev. 2015, 9, 46-50. [CrossRef]

27. Dai, Y.; Wang, W.-H. Peroxisome proliferator-activated receptor $\gamma$ and colorectal cancer. World J. Gastrointest. Oncol. 2010, 2, 159-164. [CrossRef]

28. Papi, A.; De Carolis, S.; Bertoni, S.; Storci, G.; Sceberras, V.; Santini, N.; Ceccarelli, C.; Taffurelli, M.; Orlandi, M.; Bonafè, M. PPAR $\gamma$ and RXR Ligands Disrupt the Inflammatory Cross-talk in the Hypoxic Breast Cancer Stem Cells Niche. J. Cell. Physiol. 2014, 229, 1595-1606. [CrossRef]

29. Prost, S.; Relouzat, F.; Spentchian, M.; Ouzegdouh, Y.; Saliba, J.; Massonnet, G.; Beressi, J.-P.; Verhoeyen, E.; Raggueneau, V.; Manéglier, B.; et al. Erosion of the chronic myeloid leukaemia stem cell pool by PPAR $\gamma$ agonists. Nature 2015, 525, 380-383. [CrossRef]

30. Gionfriddo, G.; Plastina, P.; Augimeri, G.; Catalano, S.; Giordano, C.; Barone, I.; Morelli, C.; Giordano, F.; Gelsomino, L.; Sisci, D.; et al. Modulating Tumor-Associated Macrophage Polarization by Synthetic and Natural PPAR $\gamma$ Ligands as a Potential Target in Breast Cancer. Cells 2020, 9, 174. [CrossRef]

31. Quintão, N.L.M.; Santin, J.R.; Stoeberl, L.C.; Corrêa, T.P.; Melato, J.; Costa, R. Pharmacological Treatment of Chemotherapy-Induced Neuropathic Pain: PPAR $\gamma$ Agonists as a Promising Tool. Front. Mol. Neurosci. 2019, 13, 907. [CrossRef] [PubMed]

32. Guan, Y.; Breyer, M.D. Peroxisome proliferator-activated receptors (PPARs): Novel therapeutic targets in renal disease. Kidney Int. 2001, 60, 14-30. [CrossRef] [PubMed]

33. Houseknecht, K.L.; Cole, B.M.; Steele, P.J. Peroxisome proliferator-activated receptor gamma (PPAR $\gamma)$ and its ligands: A review. Domest. Anim. Endocrinol. 2002, 22, 1-23. [CrossRef] 
34. Tontonoz, P.; Spiegelman, B.M. Fat and Beyond: The Diverse Biology of PPAR $\gamma$. Annu. Rev. Biochem. 2008, 77, 289-312. [CrossRef]

35. Kroker, A.J.; Bruning, J.B. Review of the Structural and Dynamic Mechanisms of PPAR $\gamma$ Partial Agonism. PPAR Res. 2015, 2015, 816856. [CrossRef]

36. Powell, E.; Kuhn, P.; Xu, W. Nuclear Receptor Cofactors in PPAR $\gamma$-Mediated Adipogenesis and Adipocyte Energy Metabolism. PPAR Res. 2006, 2007, 053843. [CrossRef]

37. Zieleniak, A.; Wójcik, M.; Wozniak, L.A. Structure and physiological functions of the human peroxisome proliferator-activated receptor $\gamma$. Arch. Immunol. Ther. Exp. 2008, 56, 331-345. [CrossRef]

38. Fang, L.; Zhang, M.; Li, Y.; Liu, Y.; Cui, Q.; Wang, N. PPARgene: A Database of Experimentally Verified and Computationally Predicted PPAR Target Genes. PPAR Res. 2016, 2016, 6042162. [CrossRef]

39. Rovito, D.; Gionfriddo, G.; Barone, I.; Giordano, C.; Grande, F.; De Amicis, F.; Lanzino, M.; Catalano, S.; Andò, S.; Bonofiglio, D. Ligand-activated PPAR $\gamma$ downregulates CXCR4 gene expression through a novel identified PPAR response element and inhibits breast cancer progression. Oncotarget 2016, 7, 65109-65124. [CrossRef]

40. Malerød, L.; Sporstøl, M.; Juvet, L.K.; Mousavi, A.; Gjøen, T.; Berg, T.O. Hepatic scavenger receptor class $\mathrm{B}$, type I is stimulated by peroxisome proliferator-activated receptor $\gamma$ and hepatocyte nuclear factor $4 \alpha$. Biochem. Biophys. Res. Commun. 2003, 305, 557-565. [CrossRef]

41. Kumar, A.P.; Quake, A.L.; Chang, M.K.X.; Zhou, T.; Lim, K.S.Y.; Singh, R.; Hewitt, R.E.; Salto-Tellez, M.; Pervaiz, S.; Clement, M.-V. Repression of NHE1 Expression by PPAR Activation Is a Potential New Approach for Specific Inhibition of the Growth of Tumor Cells in vitro and in vivo. Cancer Res. 2009, 69, 8636-8644. [CrossRef] [PubMed]

42. Tzeng, J.; Byun, J.; Park, J.Y.; Yamamoto, T.; Schesing, K.; Tian, B.; Sadoshima, J.; Oka, S.-I. An Ideal PPAR Response Element Bound to and Activated by PPAR $\alpha$. PLOS ONE 2015, 10, e0134996. [CrossRef]

43. Schulman, I.G.; Shao, G.; Heyman, R.A. Transactivation by Retinoid X Receptor-Peroxisome Proliferator-Activated Receptor $\gamma(\mathrm{PPAR} \gamma)$ Heterodimers: Intermolecular Synergy Requires Only the PPAR $\gamma$ Hormone-Dependent Activation Function. Mol. Cell. Boil. 1998, 18, 3483-3494. [CrossRef]

44. Bonofiglio, D.; Cione, E.; Qi, H.; Pingitore, A.; Perri, M.; Catalano, S.; Vizza, N.; Panno, M.L.; Genchi, G.; Fuqua, S.A.; et al. Combined Low Doses of PPAR $\gamma$ and RXR Ligands Trigger an Intrinsic Apoptotic Pathway in Human Breast Cancer Cells. Am. J. Pathol. 2009, 175, 1270-1280. [CrossRef] [PubMed]

45. Bonofiglio, D.; Cione, E.; Vizza, N.; Perri, M.; Pingitore, A.; Qi, H.; Catalano, S.; Rovito, D.; Genchi, G.; Andò, S. Bid as a potential target of apoptotic effects exerted by low doses of PPAR $\gamma$ and RXR ligands in breast cancer cells. Cell Cycle 2011, 10, 2344-2354. [CrossRef]

46. Varga, T.; Czimmerer, Z.; Nagy, L. PPARs are a unique set of fatty acid regulated transcription factors controlling both lipid metabolism and inflammation. Biochim. Biophys. Acta (BBA)-Mol. Basis Dis. 2011, 1812, 1007-1022. [CrossRef]

47. Ricote, M.; Glass, C.K. PPARs and molecular mechanisms of transrepression. Biochim. Biophys. Acta (BBA)-Mol. Cell Boil. Lipids 2007, 1771, 926-935. [CrossRef]

48. Brunmeir, R.; Xu, F. Functional Regulation of PPARs through Post-Translational Modifications. Int. J. Mol. Sci. 2018, 19, 1738. [CrossRef]

49. Marion-Letellier, R.; Savoye, G.; Ghosh, S. Fatty acids, eicosanoids and PPAR gamma. Eur. J. Pharmacol. 2016, 785, 44-49. [CrossRef]

50. Shahidi, F.; Ambigaipalan, P. Omega-3 Polyunsaturated Fatty Acids and Their Health Benefits. Annu. Rev. Food Sci. Technol. 2018, 9, 345-381. [CrossRef]

51. Geelen, A.; Schouten, J.M.; Kamphuis, C.; Stam, B.E.; Burema, J.; Renkema, J.M.S.; Bakker, E.-J.; Veer, P.V.; Kampman, E. Fish Consumption, n-3 Fatty Acids, and Colorectal Cancer: A Meta-Analysis of Prospective Cohort Studies. Am. J. Epidemiol. 2007, 166, 1116-1125. [CrossRef] [PubMed]

52. Gu, Z.; Shan, K.; Chen, H.; Chen, Y.Q. n-3 Polyunsaturated Fatty Acids and Their Role in Cancer Chemoprevention. Curr. Pharmacol. Rep. 2015, 1, 283-294. [CrossRef] [PubMed]

53. Albert, B.B.; Derraik, J.G.B.; Brennan, C.M.; Biggs, J.B.; Smith, G.C.; Garg, M.L.; Cameron-Smith, D.; Hofman, P.L.; Cutfield, W.S. Higher omega-3 index is associated with increased insulin sensitivity and more favourable metabolic profile in middle-aged overweight men. Sci. Rep. 2014, 4, 6697. [CrossRef] [PubMed] 
54. McGlory, C.; Calder, P.C.; Nunes, E.A. The Influence of Omega-3 Fatty Acids on Skeletal Muscle Protein Turnover in Health, Disuse, and Disease. Front. Nutr. 2019, 6, 144. [CrossRef] [PubMed]

55. Cardoso, C.; Afonso, C.; Bandarra, N.M. Dietary DHA and health: Cognitive function ageing. Nutr. Res. Rev. 2016, 29, 281-294. [CrossRef] [PubMed]

56. Gutiérrez, S.; Svahn, S.L.; Johansson, M.E. Effects of Omega-3 Fatty Acids on Immune Cells. Int. J. Mol. Sci. 2019, 20, 5028. [CrossRef]

57. Mansoori, A.; Sotoudeh, G.; Djalali, M.; Eshraghian, M.-R.; Keramatipour, M.; Nasli-Esfahani, E.; Shidfar, F.; Alvandi, E.; Toupchian, O.; Koohdani, F. Effect of DHA-rich fish oil on PPAR $\gamma$ target genes related to lipid metabolism in type 2 diabetes: A randomized, double-blind, placebo-controlled clinical trial. J. Clin. Lipidol. 2015, 9, 770-777. [CrossRef]

58. Edwards, I.J.; O’Flaherty, J.T. Omega-3 Fatty Acids and PPAR $\gamma$ in Cancer. PPAR Res. 2008, 2008, 358052. [CrossRef]

59. Giordano, C.; Plastina, P.; Barone, I.; Catalano, S.; Bonofiglio, D. n-3 Polyunsaturated Fatty Acid Amides: New Avenues in the Prevention and Treatment of Breast Cancer. Int. J. Mol. Sci. 2020, 21, 2279. [CrossRef]

60. Schopfer, F.J.; Lin, Y.; Baker, P.R.S.; Cui, T.; Garcia-Barrio, M.; Zhang, J.; Chen, K.; Chen, Y.E.; Freeman, B.A. Nitrolinoleic acid: An endogenous peroxisome proliferator-activated receptor ligand. Proc. Natl. Acad. Sci. USA 2005, 102, 2340-2345. [CrossRef]

61. Reddy, A.T.; Lakshmi, S.P.; Reddy, R.C. The Nitrated Fatty Acid 10-Nitro-oleate Diminishes Severity of LPS-Induced Acute Lung Injury in Mice. PPAR Res. 2012, 2012, 617063. [CrossRef] [PubMed]

62. Wang, L.; Waltenberger, B.; Pferschy-Wenzig, E.-M.; Blunder, M.; Liu, X.; Malainer, C.; Blažević, T.; Schwaiger, S.; Rollinger, J.M.; Heiss, E.H.; et al. Natural product agonists of peroxisome proliferator-activated receptor gamma (PPAR $\gamma$ ): A review. Biochem. Pharmacol. 2014, 92, 73-89. [CrossRef] [PubMed]

63. Bonofiglio, D.; Giordano, C.; De Amicis, F.; Lanzino, M.; Andò, S. Natural Products as Promising Antitumoral Agents in Breast Cancer: Mechanisms of Action and Molecular Targets. Mini-Rev. Med. Chem. 2016, 15, 596-604. [CrossRef] [PubMed]

64. Magee, P.; Pearson, S.J.; Whittingham-Dowd, J.K.; Allen, J. PPAR $\gamma$ as a molecular target of EPA anti-inflammatory activity during TNF- $\alpha$-impaired skeletal muscle cell differentiation. J. Nutr. Biochem. 2012, 23, 1440-1448. [CrossRef] [PubMed]

65. Chambrier, C.; Bastard, J.-P.; Rieusset, J.; Chevillotte, E.; Bonnefont-Rousselot, M.; Thérond, P.; Hainque, B.; Riou, J.-P.; Laville, M.; Vidal, H. Eicosapentaenoic Acid Induces mRNA Expression of Peroxisome Proliferator-Activated Receptor $\gamma$. Obes. Res. 2002, 10, 518-525. [CrossRef]

66. Marion-Letellier, R.; Butler, M.; Déchelotte, P.; Playford, R.J.; Ghosh, S. Comparison of cytokine modulation by natural peroxisome proliferator-activated receptor gamma ligands with synthetic ligands in intestinal-like Caco-2 cells and human dendritic cells-Potential for dietary modulation of peroxisome proliferator-activated receptor gamma in intestinal inflammation. Am. J. Clin. Nutr. 2008, 87, 939-948.

67. Rovito, D.; Giordano, C.; Plastina, P.; Barone, I.; De Amicis, F.; Mauro, L.; Rizza, P.; Lanzino, M.; Catalano, S.; Bonofiglio, D.; et al. Omega-3 DHA- and EPA-dopamine conjugates induce PPAR $\gamma$-dependent breast cancer cell death through autophagy and apoptosis. Biochim. Biophys. Acta (BBA)-Gen. Subj. 2015, 1850, 2185-2195. [CrossRef]

68. Yu, C.; Chen, L.-L.; Luo, H.; Chen, J.; Cheng, F.; Gui, C.; Zhang, R.; Shen, J.; Chen, K.; Jiang, H.; et al. Binding analyses between Human PPARgamma-LBD and ligands. Surface plasmon resonance biosensor assay correlating with circular dichroic spectroscopy determination and molecular docking. J. Boil. Inorg. Chem. 2004, 271, 386-397. [CrossRef]

69. Bull, A.W.; Steffensen, K.R.; Leers, J.; Rafter, J.J. Activation of PPAR in colon tumor cell lines by oxidized metabolites of linoleic acid, endogenous ligands for PPAR. Carcinogenesis 2003, 24, 1717-1722. [CrossRef]

70. Itoh, T.; Fairall, L.; Amin, K.; Inaba, Y.; Szanto, A.; Balint, B.L.; Nagy, L.; Yamamoto, K.; Schwabe, J. Structural basis for the activation of PPAR $\gamma$ by oxidized fatty acids. Nat. Struct. Mol. Boil. 2008, 15, 924-931. [CrossRef]

71. Wang, C.; Fu, M.; D’Amico, M.; Albanese, C.; Zhou, J.-N.; Brownlee, M.; Lisanti, M.P.; Chatterjee, V.K.K.; Lazar, M.A.; Pestell, R.G. Inhibition of Cellular Proliferation through IкB Kinase-Independent and Peroxisome Proliferator-Activated Receptor $\gamma$-Dependent Repression of Cyclin D1. Mol. Cell. Boil. 2001, 21, 3057-3070. [CrossRef] [PubMed] 
72. Yu, Y.; Correll, P.; Heuvel, J.V. Conjugated linoleic acid decreases production of pro-inflammatory products in macrophages: Evidence for a PPAR $\gamma$-dependent mechanism. Biochim. Biophys. Acta (BBA)-Mol. Cell Boil. Lipids 2002, 1581, 89-99. [CrossRef]

73. Mueller, M.; Jungbauer, A. Red clover extract. Menopause 2008, 15, 1120-1131. [CrossRef] [PubMed]

74. Fang, X.-K.; Gao, J.; Zhu, D.-N. Kaempferol and quercetin isolated from Euonymus alatus improve glucose uptake of 3T3-L1 cells without adipogenesis activity. Life Sci. 2008, 82, 615-622. [CrossRef]

75. Puhl, A.C.; Bernardes, A.; Silveira, R.L.; Yuan, J.; Campos, J.L.D.O.; Saidemberg, D.M.; Palma, M.S.; Cvoro, A.; Ayers, S.D.; Webb, P.; et al. Mode of Peroxisome Proliferator-Activated Receptor $\gamma$ Activation by Luteolin. Mol. Pharmacol. 2012, 81, 788-799. [CrossRef]

76. Gottlieb, A.; Yanover, C.; Cahan, A.; Goldschmidt, Y. Estimating the effects of second-line therapy for type 2 diabetes mellitus: Retrospective cohort study. BMJ Open Diabetes Res. Care 2017, 5, e000435. [CrossRef]

77. European Medicines Agency. Available online: https://www.ema.europa.eu/en/news/european-medicines-a gency-recommends-suspension-avandia-avandamet-avaglim (accessed on 10 July 2020).

78. Shang, J.; Brust, R.; Mosure, S.A.; Bass, J.; Munoz-Tello, P.; Lin, H.; Hughes, T.S.; Tang, M.; Ge, Q.; Kamenekca, T.M.; et al. Cooperative cobinding of synthetic and natural ligands to the nuclear receptor PPAR $\gamma$. eLife 2018, 7. [CrossRef]

79. Koffarnus, R.L.; A Wargo, K.; Phillippe, H.M. Rivoglitazone: A New Thiazolidinedione for the Treatment of Type 2 Diabetes Mellitus. Ann. Pharmacother. 2013, 47, 877-885. [CrossRef]

80. Pishvaian, M.J.; Marshall, J.L.; Wagner, A.J.; Hwang, J.J.; Malik, S.; Cotarla, I.; Deeken, J.F.; He, A.R.; Daniel, H.; Halim, A.-B.; et al. A phase 1 study of efatutazone, an oral peroxisome proliferator-activated receptor gamma agonist, administered to patients with advanced malignancies. Cancer 2012, 118, 5403-5413. [CrossRef]

81. Hauner, H. The mode of action of thiazolidinediones. Diabetes/Metab. Res. Rev. 2002, 18, S10-S15. [CrossRef]

82. Nanjan, M.; Mohammed, M.; Kumar, B.R.P.; Chandrasekar, M. Thiazolidinediones as antidiabetic agents: A critical review. Bioorganic Chem. 2018, 77, 548-567. [CrossRef] [PubMed]

83. Rizos, C.; Elisaf, M.; Mikhailidis, D.; Liberopoulos, E.; Liberopoulos, E. How safe is the use of thiazolidinediones in clinical practice? Expert Opin. Drug Saf. 2008, 8, 15-32. [CrossRef]

84. Zhang, F.; LaVan, B.E.; Gregoire, F.M. Selective Modulators of PPAR- $\gamma$ Activity: Molecular Aspects Related to Obesity and Side-Effects. PPAR Res. 2007, 2007, 32696. [CrossRef] [PubMed]

85. Govindarajulu, M.; Pinky, P.D.; Bloemer, J.; Ghanei, N.; Suppiramaniam, V.; Amin, R.H. Signaling Mechanisms of Selective PPAR $\gamma$ Modulators in Alzheimer's Disease. PPAR Res. 2018, 2018, 2010675. [CrossRef] [PubMed]

86. Lehmann, J.M.; Lenhard, J.M.; Oliver, B.B.; Ringold, G.M.; Kliewer, S.A. Peroxisome Proliferator-activated Receptors a and $\mathrm{g}$ Are Activated by Indomethacin and Other Non-steroidal Anti-inflammatory Drugs. J. Biol. Chem. 1997, 272, 3406-3410. [CrossRef]

87. Puhl, A.C.; Milton, F.A.; Cvoro, A.; Sieglaff, D.H.; Campos, J.L.D.O.; Bernardes, A.; Filgueira, C.S.; Lindemann, J.L.; Deng, T.; Neves, F.A.; et al. Mechanisms of Peroxisome Proliferator Activated Receptor $\gamma$ Regulation by Non-steroidal Anti-inflammatory Drugs. Nucl. Recept. Signal. 2015, 13. [CrossRef]

88. Zhou, J.; Zhang, W.; Liang, B.; Casimiro, M.C.; Whitaker-Menezes, D.; Wang, M.; Lisanti, M.P.; Lanza-Jacoby, S.; Pestell, R.G.; Wang, C. PPAR $\gamma$ activation induces autophagy in breast cancer cells. Int. J. Biochem. Cell Boil. 2009, 41, 2334-2342. [CrossRef]

89. Hulin, B.; McCarthy, P.; Gibbs, E. The glitazone family of antidiabetic agents. In Current Pharmaceutical Design; Bentham Science Publishers: Bussum, The Netherlands, 1996; Volume 2, pp. 85-102.

90. Liu, H.; Zang, C.; Fenner, M.; Possinger, K.; Elstner, E. PPAR $\gamma$ Ligands and ATRA Inhibit the Invasion of Human Breast Cancer Cells in vitro. Breast Cancer Res. Treat. 2003, 79, 63-74. [CrossRef]

91. Bonofiglio, D.; Aquila, S.; Catalano, S.; Gabriele, S.; Belmonte, M.; Middea, E.; Qi, H.; Morelli, C.; Gentile, M.; Maggiolini, M.; et al. Peroxisome Proliferator-Activated Receptor- $\gamma$ Activates p53 Gene Promoter Binding to the Nuclear Factor-кB Sequence in Human MCF7 Breast Cancer Cells. Mol. Endocrinol. 2006, 20, 3083-3092. [CrossRef]

92. Oberfield, J.L.; Collins, J.L.; Holmes, C.P.; Goreham, D.M.; Cooper, J.P.; Cobb, J.E.; Lenhard, J.M.; Hull-Ryde, E.A.; Mohr, C.P.; Blanchard, S.G.; et al. A peroxisome proliferator-activated receptor ligand inhibits adipocyte differentiation. Proc. Natl. Acad. Sci. USA 1999, 96, 6102-6106. [CrossRef]

93. Rocchi, S.; Picard, F.; Vamecq, J.; Gelman, L.; Potier, N.; Zeyer, D.; Dubuquoy, L.; Bac, P.; Champy, M.F.; Plunket, K.D.; et al. A unique PPARgamma ligand with potent insulin-sensitizing yet weak adipogenic activity. Mol. Cell 2001, 8, 737-747. [CrossRef] 
94. Henriksen, K.; Byrjalsen, I.; Qvist, P.; Beck-Nielsen, H.; Hansen, G.; Riis, B.J.; Perrild, H.; Svendsen, O.L.; Gram, J.; Karsdal, M.A.; et al. Efficacy and safety of the PPAR $\gamma$ partial agonist balaglitazone compared with pioglitazone and placebo: A phase III, randomized, parallel-group study in patients with type 2 diabetes on stable insulin therapy. Diabetes/Metab. Res. Rev. 2011, 27, 392-401. [CrossRef]

95. Lazarenko, O.P.; Rzonca, S.O.; Suva, L.; Lecka-Czernik, B. Netoglitazone is a PPAR-gamma ligand with selective effects on bone and fat. Bone 2006, 38, 74-84. [CrossRef] [PubMed]

96. Bonofiglio, D.; Qi, H.; Gabriele, S.; Catalano, S.; Aquila, S.; Belmonte, M.; Ando, S. Peroxisome proliferator-activated receptor $\mathrm{g}$ inhibits follicular and anaplastic thyroid carcinoma cells growth by upregulating p21Cip1/WAF1 gene in a Sp1-dependent manner. Endocr-Relat. Cancer 2008, 15, 545-557. [CrossRef] [PubMed]

97. Vella, V.; Nicolosi, M.L.; Giuliano, S.; Bellomo, M.; Belfiore, A.; Malaguarnera, R. PPAR- $\gamma$ Agonists as Antineoplastic Agents in Cancers with Dysregulated IGF Axis. Front. Endocrinol. 2017, 8, 31. [CrossRef] [PubMed]

98. Thu, K.; Bretones, I.S.; Mak, T.; Cescon, D.W. Targeting the cell cycle in breast cancer: Towards the next phase. Cell Cycle 2018, 17, 1871-1885. [CrossRef]

99. Feitelson, M.A.; Arzumanyan, A.; Kulathinal, R.J.; Blain, S.W.; Holcombe, R.F.; Mahajna, J.; Marino, M.; Chantar, M.L.M.; Nawroth, R.; Sánchez-García, I.; et al. Sustained proliferation in cancer: Mechanisms and novel therapeutic targets. Semin. Cancer Boil. 2015, 35, S25-S54. [CrossRef]

100. Malumbres, M.; Barbacid, M. Cell cycle, CDKs and cancer: A changing paradigm. Nat. Rev. Cancer 2009, 9, 153-166. [CrossRef]

101. Jingwen, B.; Yaochen, L.; Guojun, Z.; Bai, J.; Li, Y.; Zhang, G.-J. Cell cycle regulation and anticancer drug discovery. Cancer Boil. Med. 2017, 14, 348-362. [CrossRef]

102. Williams, G.H.; Stoeber, K. The cell cycle and cancer. J. Pathol. 2011, 226, 352-364. [CrossRef]

103. Tachibana, K.; Yamasaki, D.; Ishimoto, K.; Doi, T. The Role of PPARs in Cancer. PPAR Res. 2008, $2008,102737$. [CrossRef] [PubMed]

104. Yin, F.; Wakino, S.; Liu, Z.; Kim, S.; Hsueh, W.A.; Collins, A.R.; Van Herle, A.J.; Law, R.E. Troglitazone Inhibits Growth of MCF-7 Breast Carcinoma Cells by Targeting G1 Cell Cycle Regulators. Biochem. Biophys. Res. Commun. 2001, 286, 916-922. [CrossRef] [PubMed]

105. Yu, H.-N.; Noh, E.-M.; Lee, Y.-R.; Roh, S.-G.; Song, E.-K.; Han, M.-K.; Lee, Y.-C.; Shim, I.K.; Lee, S.J.; Jung, S.H.; et al. Troglitazone enhances tamoxifen-induced growth inhibitory activity of MCF-7 cells. Biochem. Biophys. Res. Commun. 2008, 377, 242-247. [CrossRef] [PubMed]

106. Triana-Martínez, F.; Loza, M.I.; Dominguez, E. Beyond Tumor Suppression: Senescence in Cancer Stemness and Tumor Dormancy. Cells 2020, 9, 346. [CrossRef]

107. Guicciardi, M.E.; Gores, G.J. Life and death by death receptors. FASEB J. 2009, 23, 1625-1637. [CrossRef]

108. Elmore, S.A. Apoptosis: A Review of Programmed Cell Death. Toxicol. Pathol. 2007, 35, 495-516. [CrossRef]

109. Pignatelli, M.; Sanchez-Rodriguez, J.; Santos, A.; Pérez-Castillo, A. 15-Deoxy- $\Delta-{ }^{12,14}$-prostaglandin J2 induces programmed cell death of breast cancer cells by a pleiotropic mechanism. Carcinogenesis 2004, 26, 81-92. [CrossRef]

110. Colin-Cassin, C.; Meyer, M.; Cerella, C.; Kleinclauss, A.; Monard, G.; Boisbrun, M.; Han, B.W.; Flament, S.; Grillier-Vuissoz, I.; Kuntz, S. Biotinylation enhances the anticancer effects of 15d-PGJ2 against breast cancer cells. Int. J. Oncol. 2018, 52, 1991-2000.

111. Nikhil, K.; Sharan, S.; Singh, A.K.; Chakraborty, A.; Roy, P. Anticancer Activities of Pterostilbene-Isothiocyanate Conjugate in Breast Cancer Cells: Involvement of PPAR $\gamma$. PLoS ONE 2014, 9, e104592. [CrossRef]

112. Jiang, Y.; Huang, Y.; Cheng, C.; Lu, W.; Zhang, Y.; Liu, X.; Zou, L.; Ben, Q.; Shen, A. Combination of thiazolidinedione and hydralazine suppresses proliferation and induces apoptosis by PPAR $\gamma$ up-expression in MDA-MB-231 cells. Exp. Mol. Pathol. 2011, 91, 768-774. [CrossRef]

113. Michael, M.S.; Badr, M.Z.; Badawi, A.F. Inhibition of cyclooxygenase-2 and activation of peroxisome proliferator-activated receptor-y synergistically induces apoptosis and inhibits growth of human breast cancer cells. Int. J. Mol. Med. 2003, 11, 733-736. [CrossRef] [PubMed]

114. Elstner, E.; Williamson, E.; Zang, C.; Fritz, J.; Heber, D.; Fenner, M.; Possinger, K.; Koeffler, H. Novel Therapeutic Approach: Ligands for PPAR $\gamma$ and Retinoid Receptors Induce Apoptosis in bcl-2-positive Human Breast Cancer Cells. Breast Cancer Res. Treat. 2002, 74, 155-165. [CrossRef] [PubMed] 
115. Bonofiglio, D.; Gabriele, S.; Aquila, S.; Qi, H.; Belmonte, M.; Catalano, S.; Andò, S. Peroxisome proliferatoractivated receptor gamma activates fas ligand gene promoter inducing apoptosis in human breast cancer cells. Breast Cancer Res. Treat. 2008, 113, 423-434. [CrossRef]

116. Khandia, R.; Dadar, M.; Munjhal, A.; Dhama, K.; Karthik, K.; Tiwari, R.; Yatoo, M.I.; Iqbal, H.M.N.; Singh, K.P.; Joshi, S.K.; et al. A Comprehensive Review of Autophagy and Its Various Roles in Infectious, Non-Infectious, and Lifestyle Diseases: Current Knowledge and Prospects for Disease Prevention, Novel Drug Design, and Therapy. Cells 2019, 8, 674. [CrossRef] [PubMed]

117. Yu, L.; Chen, Y.; Tooze, S.A. Autophagy pathway: Cellular and molecular mechanisms. Autophagy 2017, 14, 207-215. [CrossRef]

118. Jang, H.Y.; Hong, O.Y.; Youn, H.J.; Kim, M.G.; Kim, C.H.; Jung, S.H.; Kim, J.S. 15d-PGJ2 inhibits NF- $\mathrm{KB}$ and AP-1-mediated MMP-9 expression and invasion of breast cancer cell by means of a heme oxygenase-1-dependent mechanism. BMB Rep. 2020, 53, 212-217. [CrossRef]

119. Hong, O.-Y.; Youn, H.J.; Jang, H.-Y.; Jung, S.H.; Noh, E.-M.; Chae, H.S.; Jeong, Y.-J.; Kim, W.; Kim, C.-H.; Kim, J.-S. Troglitazone Inhibits Matrix Metalloproteinase-9 Expression and Invasion of Breast Cancer Cell through a Peroxisome Proliferator-Activated Receptor $\gamma$-Dependent Mechanism. J. Breast Cancer 2018, 21, 28-36. [CrossRef]

120. Hwang, J.-K.; Yu, H.-N.; Noh, E.-M.; Kim, J.-M.; Hong, O.-Y.; Youn, H.J.; Jung, S.H.; Kwon, K.-B.; Kim, J.-S.; Lee, Y.-R. DHA blocks TPA-induced cell invasion by inhibiting MMP-9 expression via suppression of the PPAR- $\gamma /$ NF-kB pathway in MCF-7 cells. Oncol. Lett. 2016, 13, 243-249. [CrossRef]

121. Keller, H.; Givel, F.; Perroud, M.; Wahli, W. Signaling cross-talk between peroxisome proliferator-activated receptor/retinoid $\mathrm{X}$ receptor and estrogen receptor through estrogen response elements. Mol. Endocrinol. 1995, 9, 794-804. [CrossRef]

122. Wang, X.; Kilgore, M.W. Signal cross-talk between estrogen receptor alpha and beta and the peroxisome proliferator-activated receptor gamma1 in MDA-MB-231 and MCF-7 breast cancer cells. Mol. Cell. Endocrinol. 2002, 194, 123-133. [CrossRef]

123. Bonofiglio, D. Estrogen Receptor Binds to Peroxisome Proliferator-Activated Receptor Response Element and Negatively Interferes with Peroxisome Proliferator-Activated Receptor Signaling in Breast Cancer Cells. Clin. Cancer Res. 2005, 11, 6139-6147. [CrossRef] [PubMed]

124. Rubin, G.L.; Zhao, Y.; Kalus, A.M.; Simpson, E.R. Peroxisome Proliferator-activated Receptor $\gamma$ Ligands Inhibit Estrogen Biosynthesis in Human Breast Adipose Tissue: Possible Implications for Breast Cancer Therapy. Cancer Res. 2000, 60, 1604-1608. [PubMed]

125. Pignatelli, M.; Cortés-Canteli, M.; Lai, C.; Santos, A.; Perez-Castillo, A. The peroxisome proliferator-activated receptor gamma is an inhibitor of ErbBs activity in human breast cancer cells. J. Cell Sci. 2001, 114, 4117-4126. [PubMed]

126. Catalano, S.; Mauro, L.; Bonofiglio, D.; Pellegrino, M.; Qi, H.; Rizza, P.; Vizza, D.; Bossi, G.; Andò, S. In Vivo and in Vitro Evidence That PPAR $\gamma$ Ligands Are Antagonists of Leptin Signaling in Breast Cancer. Am. J. Pathol. 2011, 179, 1030-1040. [CrossRef] [PubMed]

127. Cui, Y.; Miyoshi, K.; Claudio, E.; Siebenlist, U.; Gonzalez, F.J.; A Flaws, J.; Wagner, K.-U.; Hennighausen, L. Loss of the Peroxisome Proliferation-activated Receptor gamma (PPAR $\gamma$ ) Does Not Affect Mammary Development and Propensity for Tumor Formation but Leads to Reduced Fertility. J. Boil. Chem. 2002, 277, 17830-17835. [CrossRef]

128. Elstner, E.; Müller, C.; Koshizuka, K.; Williamson, E.A.; Park, D.; Asou, H.; Shintaku, P.; Said, J.W.; Heber, D.; Koeffler, H.P. Ligands for peroxisome proliferator-activated receptor and retinoic acid receptor inhibit growth and induce apoptosis of human breast cancer cells in vitro and in BNX mice. Proc. Natl. Acad. Sci. USA 1998, 95, 8806-8811. [CrossRef]

129. E Clay, C.; Namen, A.M.; Atsumi, G.-I.; Willingham, M.C.; High, K.P.; Kute, T.E.; Trimboli, A.J.; Fonteh, A.N.; Dawson, P.A.; Chilton, F.H. Influence of J series prostaglandins on apoptosis and tumorigenesis of breast cancer cells. Carcinogenesis 1999, 20, 1905-1911. [CrossRef]

130. Lapillonne, H.; Konopleva, M.; Tsao, T.; Gold, D.; McQueen, T.; Sutherland, R.L.; Madden, T.; Andreeff, M. Activation of Peroxisome Proliferator-activated Receptor $\gamma$ by a Novel Synthetic Triterpenoid 2-Cyano-3,12-dioxooleana-1,9-dien-28-oic Acid Induces Growth Arrest and Apoptosis in Breast Cancer Cells. Cancer Res. 2003, 63, 5926-5939. 
131. Xue, M.; Wang, Q.; Zhao, J.; Dong, L.; Ge, Y.; Hou, L.; Liu, Y.; Zheng, Z. Docosahexaenoic acid inhibited the Wnt/ $\beta$-Catenin pathway and suppressed breast cancer cells in vitro and in vivo. J. Nutr. Biochem. 2014, 25, 104-110. [CrossRef]

132. Ghosh-Choudhury, T.; Mandal, C.C.; Woodruff, K.; Clair, P.S.; Fernandes, G.; Choudhury, G.G.; Ghosh-Choudhury, N. Fish oil targets PTEN to regulate NFKB for downregulation of anti-apoptotic genes in breast tumor growth. Breast Cancer Res. Treat. 2008, 118, 213-228. [CrossRef]

133. Vibet, S.; Goupille, C.; Bougnoux, P.; Steghens, J.-P.; Goré, J.; Mahéo, K. Sensitization by docosahexaenoic acid (DHA) of breast cancer cells to anthracyclines through loss of glutathione peroxidase (GPx1) response. Free. Radic. Boil. Med. 2008, 44, 1483-1491. [CrossRef] [PubMed]

134. Kang, K.S.; Wang, P.; Yamabe, N.; Fukui, M.; Jay, T.R.; Zhu, B.T. Docosahexaenoic Acid Induces Apoptosis in MCF-7 Cells in Vitro and in Vivo via Reactive Oxygen Species Formation and Caspase 8 Activation. PLOS ONE 2010, 5, e10296. [CrossRef]

135. Rose, D.P.; Connolly, J.M. Dietary fat and breast cancer metastasis by human tumor xenografts. Breast Cancer Res. Treat. 1997, 46, 225-237. [CrossRef] [PubMed]

136. A Leslie, M.; A Abdelmagid, S.; Perez, K.H.; Muller, W.J.; Ma, D.W. Mammary tumour development is dose-dependently inhibited by $n-3$ polyunsaturated fatty acids in the MMTV-neu(ndl)-YD5 transgenic mouse model. Lipids Health Dis. 2014, 13, 96. [CrossRef] [PubMed]

137. Yee, L.D.; Agarwal, D.; Rosol, T.J.; Lehman, A.; Tian, M.; Hatton, J.; Heestand, J.; Belury, M.A.; Clinton, S.K.; Cook, J. The inhibition of early stages of HER-2/neu-mediated mammary carcinogenesis by dietary $\mathrm{n}-3$ PUFAs. Mol. Nutr. Food Res. 2012, 57, 320-327. [CrossRef]

138. MacLennan, M.B.; Clarke, S.E.; Perez, K.; Wood, G.A.; Muller, W.J.; Kang, J.X.; Ma, D.W. Mammary tumor development is directly inhibited by lifelong n-3 polyunsaturated fatty acids. J. Nutr. Biochem. 2013, 24, 388-395. [CrossRef]

139. Jiang, W.; Zhu, Z.; McGinley, J.N.; El Bayoumy, K.; Manni, A.; Thompson, H.J. Identification of a Molecular Signature Underlying Inhibition of Mammary Carcinoma Growth by Dietary N-3 Fatty Acids. Cancer Res. 2012, 72, 3795-3806. [CrossRef]

140. Yee, L.D.; Williams, N.; Wen, P.; Young, N.C.; Lester, J.; Johnson, M.V.; Farrar, W.B.; Walker, M.J.; Povoski, S.P.; Suster, S.; et al. Pilot Study of Rosiglitazone Therapy in Women with Breast Cancer: Effects of Short-term Therapy on Tumor Tissue and Serum Markers. Clin. Cancer Res. 2007, 13, 246-252. [CrossRef]

141. Straka, S.; Lester, J.L.; Cole, R.M.; Andridge, R.R.; Puchala, S.; Rose, A.M.; Clinton, S.K.; Belury, M.A.; Yee, L.D. Incorporation of eicosapentaenioic and docosahexaenoic acids into breast adipose tissue of women at high risk of breast cancer: A randomized clinical trial of dietary fish and n-3 fatty acid capsules. Mol. Nutr. Food Res. 2015, 59, 1780-1790. [CrossRef]

142. Gomes, M.A.; Jia, X.; Kolenski, I.; Duncan, A.M.; A Meckling, K. The role of background diet on the effects of eicosapentaenoic acid and docosahexaenoic acid supplementation in healthy pre-menopausal women: A randomized, cross-over, controlled study. Lipids Health Dis. 2016, 15, 168. [CrossRef]

143. Manni, A.; Richie, J.P.; E Schetter, S.; Calcagnotto, A.; Trushin, N.; Aliaga, C.; El-Bayoumy, K. Stearoyl-CoA desaturase-1, a novel target of omega-3 fatty acids for reducing breast cancer risk in obese postmenopausal women. Eur. J. Clin. Nutr. 2017, 71, 762-765. [CrossRef] [PubMed]

144. Inglis, J.E.; Kleckner, A.S.; Lin, P.-J.; Gilmore, N.J.; Culakova, E.; VanDerWoude, A.C.; Mustian, K.M.; Fernandez, I.D.; Dunne, R.F.; Deutsch, J.; et al. Excess Body Weight and Cancer-Related Fatigue, Systemic Inflammation, and Serum Lipids in Breast Cancer Survivors. Nutr. Cancer 2020, 1-11. [CrossRef] [PubMed]

145. Hershman, D.L.; Unger, J.M.; Crew, K.D.; Awad, D.; Dakhil, S.R.; Gralow, J.; Greenlee, H.; Lew, D.L.; Minasian, L.M.; Till, C.; et al. Randomized Multicenter Placebo-Controlled Trial of Omega-3 Fatty Acids for the Control of Aromatase Inhibitor-Induced Musculoskeletal Pain: SWOG S0927. J. Clin. Oncol. 2015, 33, 1910-1917. [CrossRef]

146. Fabian, C.J.; Kimler, B.F.; Phillips, T.A.; Box, J.A.; Kreutzjans, A.L.; Carlson, S.E.; Hidaka, B.H.; Metheny, T.; Zalles, C.M.; Mills, G.B.; et al. Modulation of Breast Cancer Risk Biomarkers by High-Dose Omega-3 Fatty Acids: Phase II Pilot Study in Premenopausal Women. Cancer Prev. Res. 2015, 8, 912-921. [CrossRef] [PubMed]

147. Fabian, C.J.; Kimler, B.F.; Phillips, T.A.; Nydegger, J.L.; Kreutzjans, A.L.; Carlson, S.E.; Hidaka, B.H.; Metheny, T.; Zalles, C.M.; Mills, G.B.; et al. Modulation of Breast Cancer Risk Biomarkers by High-Dose Omega-3 Fatty Acids: Phase II Pilot Study in Postmenopausal Women. Cancer Prev. Res. 2015, 8, 922-931. [CrossRef] 
148. Young, L.R.; Kurzer, M.S.; Thomas, W.; Redmon, J.; Raatz, S.K. Effect of Dietary Fat and Omega-3 Fatty Acids on Urinary Eicosanoids and Sex Hormone Concentrations in Postmenopausal Women: A Randomized Controlled Feeding Trial. Nutr. Cancer 2011, 63, 930-939. [CrossRef] [PubMed]

149. McColley, S.P.; Georgopoulos, A.; Young, L.R.; Kurzer, M.S.; Redmon, J.; Raatz, S.K. A high-fat diet and the threonine-encoding allele (Thr54) polymorphism of fatty acid-binding protein 2 reduce plasma triglyceride-rich lipoproteins. Nutr. Res. 2011, 31, 503-508. [CrossRef]

150. Raatz, S.K.; Young, L.R.; Picklo, M.J.; Sauter, E.R.; Qin, W.; Kurzer, M.S. Total dietary fat and fatty acid content modifies plasma phospholipid fatty acids, desaturase activity indices, and urinary prostaglandin $\mathrm{E}$ in women. Nutr. Res. 2012, 32,1-7. [CrossRef]

151. Young, L.R.; Raatz, S.K.; Thomas, W.; Redmon, J.; Kurzer, M.S. Total dietary fat and omega-3 fatty acids have modest effects on urinary sex hormones in postmenopausal women. Nutr. Metab. 2013, 10, 36. [CrossRef]

152. Holt, P.R.; Aleman, J.O.; Walker, J.M.; Jiang, C.S.; Liang, Y.; De Rosa, J.C.; Giri, D.D.; Iyengar, N.M.; Milne, G.L.; A Hudis, C.; et al. Docosahexaenoic acid supplementation is not anti-inflammatory in adipose tissue of healthy obese postmenopausal women. Int. J. Nutr. 2017, 1, 31-49. [CrossRef]

153. Zick, S.M.; Colacino, J.A.; Cornellier, M.; Khabir, T.; Surnow, K.; Djuric, Z. Fatigue reduction diet in breast cancer survivors: A pilot randomized clinical trial. Breast Cancer Res. Treat. 2016, 161, 299-310. [CrossRef] [PubMed]

154. Esteva, F.J.; Moulder, S.L.; Gonzalez-Angulo, A.M.; Ensor, J.; Murray, J.L.; Green, M.C.; Koenig, K.B.; Lee, M.-H.; Hortobagyi, G.N.; Yeung, S.-C. Phase I trial of exemestane in combination with metformin and rosiglitazone in nondiabetic obese postmenopausal women with hormone receptor-positive metastatic breast cancer. Cancer Chemother. Pharmacol. 2012, 71, 63-72. [CrossRef] [PubMed]

(C) 2020 by the authors. Licensee MDPI, Basel, Switzerland. This article is an open access article distributed under the terms and conditions of the Creative Commons Attribution (CC BY) license (http://creativecommons.org/licenses/by/4.0/). 